NBER WORKING PAPER SERIES

SPATIAL COMPETITION, INNOVATION AND INSTITUTIONS:
THE INDUSTRIAL REVOLUTION AND THE GREAT DIVERGENCE

\author{
Klaus Desmet \\ Avner Greif \\ Stephen Parente \\ Working Paper 24727 \\ http://www.nber.org/papers/w24727 \\ NATIONAL BUREAU OF ECONOMIC RESEARCH \\ 1050 Massachusetts Avenue \\ Cambridge, MA 02138 \\ June 2018
}

We benefitted from helpful comments from seminar participants at Brown, CEU, Cleveland Fed, Dartmouth, HEC, Houston, Humboldt, U Javeriana, LSU, Miami, Penn, Princeton, St. Louis Fed and Texas A\&M. We thank Wolfgang Keller for sharing historical prefecture-level data on China. The views expressed herein are those of the authors and do not necessarily reflect the views of the National Bureau of Economic Research.

NBER working papers are circulated for discussion and comment purposes. They have not been peer-reviewed or been subject to the review by the NBER Board of Directors that accompanies official NBER publications.

(C) 2018 by Klaus Desmet, Avner Greif, and Stephen Parente. All rights reserved. Short sections of text, not to exceed two paragraphs, may be quoted without explicit permission provided that full credit, including $\odot$ notice, is given to the source. 
Spatial Competition, Innovation and Institutions: The Industrial Revolution and the Great Divergence

Klaus Desmet, Avner Greif, and Stephen Parente

NBER Working Paper No. 24727

June 2018

JEL No. N10,O11,O14,O31,O43

\section{ABSTRACT}

A market-size-only theory of industrialization cannot explain why England developed nearly two centuries before China. One shortcoming of such a theory is its exclusive focus on producers. We show that once we incorporate the incentives of factor suppliers' organizations such as craft guilds, industrialization no longer depends on market size, but on spatial competition between the guilds' jurisdictions. We substantiate our theory (i) by providing historical and empirical evidence on the relation between spatial competition, craft guilds and innovation, and (ii) by showing the calibrated model correctly predicts the timings of the Industrial Revolution and the Great Divergence.

Klaus Desmet

Department of Economics and

Cox School of Business

Southern Methodist University

3300 Dyer, Suite 301

Dallas, TX 75205

and CEPR

and also NBER

kdesmet@smu.edu

Avner Greif

Department of Economics

Stanford University

Stanford, CA 94305

avner@stanford.edu
Stephen Parente

University of Illinois

Urbana, IL 61801

parente@illinois.edu 


\title{
Spatial Competition, Innovation and Institutions: The Industrial Revolution and the Great Divergence*
}

\author{
Klaus Desmet \\ SMU, NBER and CEPR
}

\author{
Avner Greif \\ Stanford University
}

\author{
Stephen L. Parente \\ University of Illinois \\ at Urbana-Champaign
}

May 2018

\begin{abstract}
A market-size-only theory of industrialization cannot explain why England developed nearly two centuries before China. One shortcoming of such a theory is its exclusive focus on producers. We show that once we incorporate the incentives of factor suppliers' organizations such as craft guilds, industrialization no longer depends on market size, but on spatial competition between the guilds' jurisdictions. We substantiate our theory (i) by providing historical and empirical evidence on the relation between spatial competition, craft guilds and innovation, and (ii) by showing the calibrated model correctly predicts the timings of the Industrial Revolution and the Great Divergence.
\end{abstract}

Keywords: Industrial Revolution, Great Divergence, craft guilds, spatial competition, inter-city competition, market size, endogenous institutions, innovation, adoption of technology

JEL Codes: N10, O11, O14, O31, O43

\section{Introduction}

Why do some countries develop much earlier than others? Why was England the first nation to experience sustained increases in its living standard? One common answer, dating back to Adam Smith (1776), emphasizes increases in market size in the period leading up to the Industrial Revolution 1 Larger markets, it is argued, made it more profitable for producers to incur the fixed costs of introducing modern technologies that favored large-scale manufacturing, thus spurring industrialization. Although the assertion that market size matters is reasonable when comparing England to other European countries ${ }^{2}$ it is far less compelling when comparing England to China

\footnotetext{
*Desmet: Department of Economics and Cox School of Business, Southern Methodist University. E-mail: kdesmet@smu.edu; Greif: Department of Economics, Stanford University. E-mail: avner@stanford.edu.; Parente: Department of Economics, University of Illinois. E-mail: parente@illinois.edu. We benefitted from helpful comments from seminar participants at Brown, CEU, Cleveland Fed, Dartmouth, HEC, Houston, Humboldt, U Javeriana, LSU, Miami, Penn, Princeton, St. Louis Fed and Texas A\&M. We thank Wolfgang Keller for sharing historical prefecture-level data on China.

${ }^{1}$ See, for example, Kremer (1993), Kelly (1997), Peretto (1998), and Desmet and Parente (2012).

${ }^{2}$ The evidence on whether market size was greater in England than in other Western European countries is mixed. Shiue and Keller (2007), for instance, supports this view, whereas Daudin (2010) does not.
} 
for the simple reason that, by almost any measure, markets were larger in China in the pre-modern period. Even upon gaining access to the modern technologies of the West following the Opium Wars, China failed to industrialize until the twentieth century, giving rise to the so-called Great Divergence between the West and the East.

This paper argues that a market-size-only theory of the Industrial Revolution is inadequate because it ignores the incentives of other actors in the economy, particularly those with interests vested in the status quo, to counter the efforts of would-be innovators and derail the industrialization process. On the eve of the Industrial Revolution, these actors were, to a large extent, craftsmen who expected a reduction in their earnings due to the diffusion of new technologies. Faced with the prospect of lower earnings, these factor suppliers reacted by organizing themselves with the goal of preventing the introduction of modern modes of production. In many instances, this response involved a transformation of existing professional societies, such as craft guilds, from organizations with some positive economic or social significance, to ones bent on blocking modern technology ${ }^{3}$ In our view, the endogenous evolution of these institutions in China and England is of critical importance for understanding the Industrial Revolution and the Great Divergence.

The key tenet of this paper is that once we allow for the emergence of organized groups of factor suppliers, industrialization no longer depends on the size of the market, but on the degree of spatial competition between jurisdictions. As the city, and not the nation, was the center of power and authority in the late medieval period, and as craft guilds and trade associations operated mostly at the city level, the relevant concept of a jurisdiction in this era was the city. Spatial competition between jurisdictions (cities) matters because an industry in a jurisdiction (city) stands to realize larger profits by introducing modern technologies when competition between producers in different jurisdictions (cities) intensifies. With strong enough spatial competition, these profits become sufficiently large to overcome the resistance by craftsmen, thereby weakening the growth-inhibiting institutions to the point where industrialization occurs. This paper's premise is that spatial or inter-city competition in England became intense enough in the mid-eighteenth century for the craft guilds to end their resistance to technological change, whereas in China this had to wait until the twentieth century.

Though spatial competition and market size are related concepts, they differ in a crucial way. Whereas market size captures the ease by which producers have access to consumers, both in their own city and in other locations, spatial competition measures the ease by which producers in one city are able to capture consumers in other cities. Although greater inter-city competition implies a bigger market size, the reverse is not always true. For example, an increase in the population size of cities obviously increases the market size for producers in these cities but it does not make it easier

\footnotetext{
${ }^{3}$ As we will discuss later, the aim of craft guilds was of course not limited to dictating production processes. Moreover, the craft guild was not the only way to organize opposition to labor-saving technology. Another common way of resisting was through labor riots.
} 
for producers to capture consumers from other cities if barriers or distances are sufficiently large so that there is no trade between cities. This difference translates into an important asymmetry in our theory: whereas inter-city competition affects both the incentives of producers to industrialize and the willingness of factor suppliers associated with the status quo to go along with industrialization, market size per se only affects the producers' returns from introducing modern technologies. Thus, an increase in market size without an increase in inter-city competition will not change these factor suppliers' incentives to end their resistance to technological change. Market-size-only theories of the Industrial Revolution are therefore incomplete, and bound to lead to erroneous conclusions.

Inspired by the historical evidence, we develop a model that shows how the degree of spatial competition affects the incentives of producers to introduce labor-saving technology and the incentives of incumbent workers to resist. The model consists of two cities or regions, each with a continuum of monopolistically competitive industrial sectors and a perfectly competitive agricultural hinterland. For each industrial good, there are two production technologies: an artisanal one, which all producers start out using, and a modern one, which can be adopted. The modern technology has two advantages: it can employ unskilled workers drawn from the hinterland, and it is characterized by greater output per production worker. However, it comes at the disadvantage of requiring a fixed adoption cost. The assumption that the modern technology does not require skilled labor provides the incentives for artisans to form groups to block the introduction of the modern technology. These are the types of institutions whose endogenous evolution we study in this paper.

The model aims to capture the intuition that stronger inter-city competition makes varieties produced in different cities more substitutable. To that end, we choose a preference construct that yields a price elasticity of demand that is increasing in the intensity of competition 4 As a result, when spatial competition is stronger, mark-ups fall and firms must become larger to break even. This increases the gains from switching to the modern technology because a larger firm can spread the fixed cost of adoption over a greater quantity of output. Therefore, more intense spatial competition increases the incentives of firms to adopt the modern technology. Spatial competition also affects the incentives of skilled workers to organize for the purpose of blocking the modern technology's introduction for the simple reason that they face the unpleasant prospect of seeing their wage earnings decrease as they must compete with unskilled workers from the hinterland. Firms in a given industry and city must overcome this resistance if they want to operate the modern technology. They can only do so if industry profits are sufficiently large to compensate skilled workers for any reduction in earnings 5 Resistance ends and the economy takes off when

\footnotetext{
${ }^{4}$ In particular, we choose a preference construct based on Lancaster's (1979) trade in ideal variety model, which in turn is an extension of Hotelling (1929). This preference structure and the implied mechanism is at the heart of Helpman and Krugman (1985) and Hummels and Lugovskyy (2009).

${ }^{5}$ The use of industry profits to buy out craftsmen is meant to capture a variety of methods employed to break worker resistance. A good example were the poor laws, financed by local taxes and put in place to help displaced
} 
profits reach this point.

Because the profitability thresholds are different for producers and skilled craftsmen, the model predicts three stages in a nation's trajectory. Starting off in a situation where spatial competition is weak, either because cities are small, transport costs are large, or distances between cities are big, no firm can pay the fixed innovation cost associated with making the new production process operational. In this case the equilibrium is characterized by all firms in all industries and cities using the artisanal technology and no technology-blocking guilds existing anywhere. As spatial competition strengthens, a first threshold is reached where an individual firm in a given city and industry becomes large enough so that its profits cover the fixed innovation cost. In spite of this, no firm in that city and industry is able to switch to the modern technology because the profits are too small to compensate the incumbent skilled workers for their reduced wages, prompting organized opposition by craft guilds. In this case, the equilibrium is characterized by all firms using the artisanal technology and guilds existing in all industries and cities. It is only when spatial competition becomes sufficiently intense that the second threshold is met where industry profits from innovation are large enough to compensate the skilled workers. At that point guilds disband, resistance to technological change ceases, firms innovate and the economy takes off.

Importantly, whereas an increase in city size, if large enough, is sufficient for guilds to form, it is never sufficient, per se, for guilds to end their resistance and for industrialization to take hold. An increase in own city size works like a reduction in transportation costs or distance between cities to affect the date the first profit threshold is reached, but it does nothing with respect to the second profit threshold. This is the key result of the model. To understand its intuition, it is useful to consider a world where cities are so distant that there is no inter-city trade. For a firm to find it profitable to introduce the modern technology, it must be able to capture customers at the expense of other firms in its industry. As city size becomes larger, this becomes easier, because varieties are more substitutable. Thus, even in the absence of inter-city trade, with a large enough increase in city size, an innovating firm will be able to capture enough customers from noninnovating competitors so as to justify paying the fixed cost of adopting the modern production process. However, once this happens and the skilled workers form a guild to block adoption by any firm in their city and industry, further increases in city size will not change the incentives of the guild to resist the modern technology if there is no inter-city trade. Given that the guild is organized at the level of the city and industry, its resistance can only be overcome if profits of all firms in its city are large enough to compensate its members for the reduction in wages. This is impossible in the absence of inter-city trade. Since household expenditures on a particular good are independent of the technology used, industry revenues (and profits) only increase if the innovating city can gain customers at the expense of the non-innovating city. Inter-city trade, and not intra-city trade, is 
thus critical for an economy's take-off.

To evaluate the historical relevance of the causal relation between spatial competition and industrialization, no single piece of evidence or methodology is perhaps sufficient. We therefore take a multifaceted approach, providing empirical, historical and quantitative support for our conjecture. In particular, we supply five different types of evidence, which together suggest that inter-city competition was an important determinant of the timing and location of the Industrial Revolution. First, using city size and location data, we quantify how spatial competition increased in England between 1600 and 1800. Using the same metric, we show that China at the end of the nineteenth century was about 200 years behind England. These observations form the starting point of our theory. Second, we provide a historical account of guilds in England, as they relate to spatial competition and innovation. In particular, we show that the degree of spatial competition affected the prevalence and intensity of resistance to labor-saving technologies. Third, we use patent data collected by Woodcroft (1854), spanning the time period from 1620 to 1823, to empirically show that locations in England that were subject to stronger inter-city competition were more innovative.

Fourth, we undertake a calibration exercise to examine whether the model is quantitatively consistent with England's development. More specifically, using measures of spatial competition between 1400 and 1600, we calibrate the model to the date when English guilds started blocking the introduction of labor-saving technologies on a large scale, and then determine the date predicted by our model when resistance should have ended, given the degree of spatial competition in England between 1600 and 1850. We find that the model predicts the timing of the Industrial Revolution fairly well.

Fifth, as a final assessment, we apply our model to the Great Divergence between China and England. Living standards diverged dramatically between China and England during the Industrial Revolution ${ }^{6}$ To examine if differences in spatial competition could have contributed to the Great Divergence, we examine the predictions of our calibrated model for resistance to labor-saving technology in China. Using Chinese data on spatial competition between 1700 and 1900, the model predicts that technology-blocking guilds in China should have survived well into the twentieth century, generating the type of divergence that occurred between the West and the East. To complete the application of our theory to China's development, we provide historical evidence showing how the emergence of European-style professional guilds in China coincided with the introduction of new labor-saving technologies from the West.7

The literature that seeks to understand why the Industrial Revolution first occurred in

\footnotetext{
${ }^{6}$ Although Pomeranz (2000) argues that on the eve of the Industrial Revolution living standards were comparable in the more developed parts of China and England, recent research has shown that there was already an important gap in favor of England in the preindustrial period (Broadberry and Gupta, 2006; Allen et al., 2011). Of course, any pre-existing gap increased substantially during the nineteenth century.

${ }^{7}$ To be precise, our model can account for China's resistance to industrialization in the second half of the nineteenth century, once it got access to Western innovations. Our theory is about the incentives to adopt labor-saving technologies; it remains silent on why China did not have more indigenous innovation during the nineteenth century.
} 
England is extensive. Diverse explanations abound, some of which are: proximity to cheap energy (Pomeranz, 2000), greater patience or stronger preferences for education (Galor and Moav, 2002; Clark, 2007), better institutions (North, 1981; Mokyr, 1990), and market size and integration (Voigtländer and Voth, 2006; Shiue and Keller, 2007; Desmet and Parente, 2012).8 Among the subset of papers that focuses on market size, none suggests that the degree of spatial competition was relevant. Indeed, in these other theories, an increase in population or a decrease in trade costs have the same impact on innovation. That is not the case in our theory: an increase in market size in the absence of trade is not enough to bring about the economy's take-off.

Our paper is related to at least three other strands in the literature. One strand is the literature on the importance of competition for innovation. Empirical evidence in favor of the positive effect of competition includes Nickell (1996), Galdón-Sánchez and Schmitz (2002) and Aghion et al. (2005). There are also a large number of theoretical papers that describe mechanisms whereby stronger competition leads to more innovation. Of particular note is the paper by Desmet and Parente (2010), which uses the same preference construct as in this paper to show how an increase in market size facilitates technological change. Although we borrow their basic setup, there are some key differences, the most important one being the endogenous formation of guilds that block the introduction of more productive technology. As a result, in our paper spatial competition, rather than market size, is what drives take-off.

Another strand is the literature on technology-blocking institutions. The importance of resistance to the introduction of more productive technology by special interests in the context of the Industrial Revolution is a prominent theme in the work of Morison (1966) and Mokyr (1990). Important theoretical papers in this area include Krusell and Rios-Rull (1996), Parente and Prescott (1999) and Dinopoulos and Syropoulos (2007). The two most closely related papers are Holmes and Schmitz (1995) and Desmet and Parente (2014). In Holmes and Schmitz (1995), although trade is likewise shown to eliminate resistance, there is no role for local market size and the theory remains silent on how an economy escapes an equilibrium where both regions block innovation. In Desmet and Parente (2014), although workers form guilds or unions to block the introduction of a better production process until they can be defeated, there is no role for spatial competition and geography in their break-up because guilds form at the firm level rather than at the industry level.

A last strand is the vast economic history literature on guilds and their attitude towards innovation. Although scholars disagree on the precise role of guilds in economic growth, there is a broad consensus on two key facts that are important for our theory $!^{9}$ First, although craft guilds did not start off as anti-competitive organizations bent on slowing down technological progress, they increasingly turned anti-technology when innovation threatened jobs (Epstein, 1998; Mokyr,

\footnotetext{
${ }^{8}$ For a comprehensive list, see McCloskey (2010).

${ }^{9}$ For different views on the role of guilds, see, for example, Smith (1776), Pirenne (1936), Hickson and Thompson (1991), Epstein (1998, 2008), Richardson (2004), Ogilvie (2008) and De la Croix, Doepke and Mokyr (2018).
} 
1997). Second, there was less resistance to new technologies when spatial competition was stronger. Cities relaxed guilds regulations when faced with stronger competition from the hinterland, and adoption of new labor-saving machinery was more likely when nearby locations were doing the same (Randall, 1991).

The rest of the paper is organized as follows. Section 2 provides historical and empirical evidence for England on the relation between spatial competition, guild resistance and innovation. Section 3 presents the model and analyzes the theoretical interaction between the spatial distribution of cities, the incentives of firms to innovate, and the incentives of guilds to resist. Section 4 examines the quantitative predictions of our theory in a calibration of the model to the pre-Industrial Revolution history of England. Section 5 applies the theory to the Great Divergence by both examining the predictions of our calibrated model for China's development and by documenting the history of guilds in China. Section 6 concludes.

\section{Spatial Competition, Guilds and Innovation in England}

In this section we provide evidence that spatial competition was important for England's economic ascent. The section begins by constructing measures of spatial competition in England, documenting their large increases between 1400 and 1850. It then describes the history of the craft guilds and their attitude toward innovation. Finally, using these measures of spatial competition, as well as case studies of the various craft guilds on the eve of the Industrial Revolution, it makes a case that innovation and guild resistance depended on the degree of spatial competition.

\subsection{The Evolution of Spatial Competition}

The main claim of this paper is that the increase in spatial competition was instrumental to England's take-off and industrial development. In this subsection we document the change in intercity competition from the pre-modern period to the Industrial Revolution in England. To measure inter-city competition over time, we use historical data on city populations from Bairoch et al. (1988). We focus on the years 1400, 1600, 1700, 1750, 1800 and 1850. In each of those years, we restrict our analysis to cities that had a population of at least 5,00010

Before turning to the construction of different measures of the degree of spatial competition, we report average city size over time. As can be seen in Panel A of Table 1, average city size roughly doubled between 1400 and 1800. Although informative, average city size does not capture the degree of spatial competition that characterized the English economic landscape in this period, for the simple reason that it ignores inter-city distances.

\footnotetext{
${ }^{10}$ The Bairoch data set covers the 800 to 1850 period and includes population data for all locations that in at least one year reached a size of 5,000 inhabitants.
} 
Table 1: Spatial Competition in England

\begin{tabular}{|c|c|c|c|c|c|c|}
\hline Year & 1400 & 1600 & 1700 & 1750 & 1800 & 1850 \\
\hline \multicolumn{7}{|c|}{ A. Average City Size (thousands) } \\
\hline & 11.2 & 19.1 & 25.1 & 28.0 & 21.2 & 50.8 \\
\hline \multicolumn{7}{|c|}{ B. Population access $\leq 20 \mathrm{~km}\left(S_{1}\right.$, thousands $)$} \\
\hline & 0.0 & 0.0 & 1.3 & 5.2 & 73.8 & 190.6 \\
\hline \multicolumn{7}{|c|}{ C. Population access, spatial decay $\gamma=1.5\left(S_{2}\right.$, thousands $)$} \\
\hline & 0.0 & 0.2 & 0.6 & 0.8 & 4.1 & 11.6 \\
\hline \multicolumn{7}{|c|}{ D. Distance to reach same number of consumers $\left(S_{3}, \mathrm{~km}\right)$} \\
\hline & 93 & 70 & 44 & 44 & 21 & 21 \\
\hline
\end{tabular}

Measures of Spatial Competition. When measuring the degree of spatial competition faced by a city, we aim to capture the ease by which an industry of that city can sell to customers of other cities. Since we are interested in inter-jurisdictional competition, we interpret spatial competition as inter-city competition. As we will show later, this is the measure that is relevant for our theory. Since there is no single accepted measure of inter-city competition, we construct three different indices. We start by introducing some notation. Denote the set of cities by $\mathcal{R}$, with $r \in \mathcal{R}$ referring to a particular city; denote the distance between cities $r$ and $r^{\prime}$ by $\delta^{r r^{\prime}}$; and denote the population size of city $r$ by $L^{r}$.

Our first measure of the spatial competition faced by city $r$ is the total population of other cities located within a certain radius $\delta$. This simple measure, which we denote by $S_{1}^{r}$, is defined as

$$
S_{1}^{r}=\sum_{r^{\prime} \in \mathcal{R}, r^{\prime} \neq r, \delta^{r r^{\prime}}<\delta} L^{r^{\prime}} .
$$

Since our theoretical results will depend on the capacity of selling to customers located in other cities, we exclude the city's own population in (1). In light of the era we study, we set $\delta$ to 20 $\mathrm{km}$, based on the idea that a $40 \mathrm{~km}$ roundtrip was close to the upper limit of travel in a single day. As can be seen in Panel B of Table 1, according to this measure there was effectively no intercity competition in England prior to 1600. Inter-city competition increased thereafter, especially between 1700 and 1800, when the access to consumers outside the own city rose from 1,000 to 74,000 people. This increase continued in the nineteenth century, with $S_{1}^{r}$ reaching 191,000 people in 1850 .

An alternative way of measuring spatial competition is to use a distance-weighted measure of the access to consumers in other cities. As such, our second measure of the spatial competition faced by city $r$, referred to as $S_{2}^{r}$, is defined as

$$
S_{2}^{r}=\sum_{r^{\prime} \in \mathcal{R}, r^{\prime} \neq r} L^{r}\left(\delta^{r r^{\prime}}\right)^{-\gamma}
$$


where $\gamma \geq 0$. The greater the value of $\gamma$, the smaller the weight given to distant populations. Panel C reports our estimates of $S_{2}^{r}$ for $\gamma$ equal to 1.5 with distances measured in kilometers ${ }^{11}$ As in the case of our first measure, the sharp growth in inter-city competition starts in 1700 . In the eighteenth century alone, $S_{2}^{r}$ experienced a seven-fold increase.

Our final measure of spatial competition is the average distance for a city to reach a population equivalent to its own size. Of the three measures, this is the most relevant one for our theory, as it will help to predict when guilds end their resistance to labor-saving technologies. To construct this measure, define for each city $r$ a vector of which the elements $L_{i}^{r}$ represent the populations of all other cities, ordered by their distances to $r$. That is, $L_{1}^{r}$ is the population of the closest city to $r, L_{2}^{r}$ is the population of the second-closest city to $r$, and so on. Likewise, for each city $r$, define a second vector of which the elements $\delta_{i}^{r}$ represent the distances to the other cities, again ordered from the closest city to the most far-away city. With these two vectors, we can then define our third measure of spatial condition as

$$
\begin{gathered}
S_{3}^{r}=\sum_{i=1}^{\bar{\iota}} \delta_{i}^{r} L_{i}^{r} / \sum_{i=1}^{\bar{\iota}} L_{i}^{r} \\
\text { where } \bar{\iota}=\operatorname{argmin} \sum_{i=1}^{\bar{\iota}} L_{i}^{r} \\
\text { s.t. } \sum_{i=1}^{\bar{\iota}} L_{i}^{r} \geq L^{r} \\
L_{\bar{\iota}}^{r}=L^{r}-\sum_{i=1}^{\bar{\iota}-1} L_{i}^{r} .
\end{gathered}
$$

As can be seen in Panel D of Table 1, this measure suggests that inter-city competition started to increase as far back as 1400. The average distance to reach the same number of consumers fell from $93 \mathrm{~km}$ in 1400 to $44 \mathrm{~km}$ in 1700. During the eighteenth century, this average distance continued to drop, reaching $21 \mathrm{~km}$ in 1800 .

Taken together, all three measures document an increase in spatial competition in the era leading up to the Industrial Revolution. The Industrial Revolution itself may, of course, have further strengthened spatial competition, but it cannot explain the initial increase in inter-city competition that pre-dated industrialization. In other words, the substantial strengthening of inter-city competition between 1400 and 1750 must have happened for reasons other than largescale industrialization. In addition, the rise in spatial competition during the eighteenth century reported in Table 1 constitutes, if anything, a lower bound, as it does not factor in the decline in transport costs associated with the major expansion of turnpikes and canals during that same time

\footnotetext{
${ }^{11}$ Using data for many countries, Jacks et al. (2011) find a value of 1.2 for the time period 1870-1913. Given the dearth of historical evidence, an alternative strategy is to use present-day evidence from developing countries as a proxy. Daumal and Zignago (2010) estimate an elasticity of 1.9 for Brazil. As a midpoint between these two estimates, we use $\gamma=1.5$.
} 
period (Szostak, 1991; Bogart, 2005).

\subsection{The Rise and Decline of Guilds and their Reaction to Innovation}

In this subsection we describe the history of guilds in England, focusing on their rise, their decline and their reaction to the introduction of labor-saving and other types of innovation. We will show that guilds, though originally not created as organizations bent on resisting innovation, over time increasingly turned against the introduction of more productive technologies, especially when labor-saving in nature.

Before discussing the role of craft guilds in resisting industrialization, we want to clarify that we do not claim that their existence was a necessary condition for modern technology to be opposed. There are examples of factor suppliers not previously part of a guild attempting to block the introduction of new modes of production. The Luddites and their machine-breaking attempts of 1811 and 1812 are a case in point. Nor do we claim that the existence of craft guilds was a sufficient condition for resistance, although the historical evidence strongly suggests that it enhanced the ability of craftsmen to act as a group in their efforts to block the adoption of technology. Despite these caveats, we nevertheless think it is useful to organize our discussion around the craft guilds because of the large number of well-documented cases where these organizations fiercely resisted the introduction of modern modes of production on the eve of the Industrial Revolution.

Rise and decline of guilds. The emergence of guilds was an integral part of the broader process of social transformation that transpired in Europe during the late medieval period. Large kinship groups, responsible for public goods in earlier times, were on the decline. As neither the state nor the church was sufficiently strong to fill this void, European society responded by organizing itself around corporations such as communes, city-states, monasteries and military orders that, in the words of Greif (2006), were "intentionally created, voluntary, interest-based, and self-governed permanent association $[\mathrm{s}] "$.

One manifestation of this transformation was the birth of the guilds. The type of guild (also referred to as hansa, gild, company, livery, or mystery) of relevance here was an association of people with the same (usually local) economic interests. Two types dominated: the merchant guild, an organization of traders engaged in some form of exchange (e.g., retail, wholesale, export, staples, etc.), and the craft guild, an organization of craftsmen specialized in a particular profession (e.g., tanning, dying, wool, cloth, etc.). Historically, merchant guilds emerged prior to craft guilds and declined earlier as well. In England, merchant guilds had become largely insignificant by the end of the fifteenth century because royal charters guaranteed urban residents toll-free trade throughout the kingdom, thus eliminating the main reason for the merchant guilds' existence (Seligman, 1887).

The craft guilds, in contrast, adapted to the changing economic landscape and thrived for a much longer period. Up until the end of the fifteenth century craft guilds continued to serve mainly 
as social organizations in which people of the same profession were engaged in religious activities and mutual assistance. This is apparent in the most comprehensive dataset on English guilds, which contains information on over 1400 guilds established mainly prior to 1492 Of the 639 guilds with known regulations, only 110 of them regulated the economic activity of their members, whereas the other 529 regulated non-economic activities, such as religious ceremonies and mutual assistance.

That some of these guilds already regulated the economic activities of their members in the fifteenth century reflects the guilds' gradual transformation toward self-interested economic institutions ${ }^{13}$ During this transition, guilds became more numerous and economically more important 14 According to Gadd and Wallis (2002), perhaps as many as three-quarters of the male population in London belonged to a guild by the mid-sixteenth century. Their growing ranks and power were not limited to large urban centers. In small towns, the increasing role that local authorities assumed in providing public goods and social services motivated them to delegate regulatory powers to the craft guilds.

By the seventeenth century, the craft guilds had completed their transition from being primarily social institutions, providing mutual support, to rent-extracting institutions. According to Hibbert (1891), "the old Gilds [sic], which had lived through the shocks of the Reformation, and the Elizabethan changes, had quite altered their character. The new ones which had arisen differed widely from the old fraternities. Instead of being brotherhoods of craftsmen desirous of advancing the public weal, they were now mere societies of capitalists, intent only on private and personal advantage... There is a constant endeavor to restrict the companies to favored individuals. Every 'foreigner' is subjected to a heavy fine, which grows larger in amount as the companies feel the trade slipping from their hands in spite of their desperate endeavors to restrict it." (p. 103). It was this transformation that Adam Smith (1776) emphasized in the Wealth of Nations when he described the craft guilds as rent-seeking organizations that limited entry through an excessively lengthy seven-year apprenticeship system 15

Craft guilds operated in this capacity up until the nineteenth century, when their influence

\footnotetext{
${ }^{12}$ The Database English Guilds was composed by Gary Richardson at UC Irvine.

${ }^{13}$ In fact, the evidence on craft guilds protecting their members from the competitive effects of market integration shows that this transition started as early as the second half of the fourteenth century. Similar to labor-saving technology in later centuries, market integration threatened the capacity of some workers to earn a living. Faced with this prospect, many craft guilds petitioned market-related privileges. For example, as documented by Kleineke (2006), there was a large increase in the number of market-related privileges in the Greater London area between 1300 and 1400 .

${ }^{14}$ In 1363 a royal decree mandated that citizens were obliged to join a guild and not leave it (Act 37, Edward III, C. 5) . All craftsmen "shall each choose his own mystery [guild] ... and having so chosen it, he should henceforth use no other".

${ }^{15}$ This same negative perception is echoed by Pirenne (1936, p. 185-186) who argued that the main aim of the craft guilds was to "protect the artisan, not just from external competition, but also from the competition of his fellow-members".
} 
began to wane (Gadd and Wallis, 2002; Britnell, 2008). Officially, the craft guilds in England were abolished in 1835 under the Municipal Corporations Act, which stated that "every person in any borough may keep any shop for the sale of all lawful wares and merchandises by wholesale or retail, and use every lawful trade, occupation..." (Gross, 1890, p. 165). However, even before this official decree, craft guilds in England were in a state of decline, both in terms of power and membership. Many had disbanded of their own accord whereas others dissolved due to government pressure well before 1835 (Epstein, 2008; Binfield, 2004; Gadd and Wallis, 2002; Randall, 1991). The lack of serious resistance in England to removing guild privileges in 1835 suggests that the craft guilds were already weakened economically and politically. In this sense, it is more appropriate to treat their decline as endogenous to the changing economic environment.

Reaction to innovation. The attitude of craft guilds to innovation mirrors their transformation from benevolent societies to predatory organizations. In their early, social club period, guilds were not particularly hostile to innovation. In fact, innovation in this period contributed to the growth of the guilds. With the arrival of new goods and technologies to towns, new crafts and professions were created, which would then be organized into guilds. Over time, as guilds became predatory, they objected to innovations that threatened their power and livelihoods 16 Not that guilds objected to the introduction of every new technology: Epstein (1998), for example, documents that innovations aimed at either saving capital or enhancing skills were generally not frowned upon. However, it was a different matter with respect to labor-saving technology, the introduction of which was almost always met with fierce resistance.

According to Randall (1991), craft guilds used three different methods to block the introduction of labor-saving technology in their industry: legal appeals, industrial actions, and violence. Initially, legal petitions seem to have been the most common form of resistance employed by the craft guilds. In trying to protect their livelihoods, these petitions were often supported by the judiciary. In an analysis of English patents and legal cases, Dent (2007) notes that "the legal decisions of the period confirm that the maximization of employment was a priority of the elites". Similarly, Letwin (1954), examining English legal writings, concludes that there was a common law right to work, "predicated on an economic system that would protect the established trades from competition".

Labor-saving innovations accelerated during the period leading up to the Industrial Revolution. According to MacLeod (1998, p. 170), between the decade of 1660 and the decade of 1790,

\footnotetext{
${ }^{16}$ The apprenticeship system in England, as enshrined in the Statute of Artificers of 1563, is considered by some to be an example of a regulation slowing down technological change. This is not to say that the apprenticeship system did not have its virtues. As emphasized by Epstein (1998) and De la Croix, Doepke and Mokyr (2016), it played an important role in the training and transmission of human capital, which was key to upholding the quality of locally produced goods. Regardless of the initial impact of the apprenticeship system, it eventually acted as a brake on progress for the simple reason that its stipulations, intended to ensure the quality of a product, ended up curtailing experimentation and innovation (Mokyr, 1998).
} 
there was a 7 -fold increase in the number of patents (and a 3-fold increase in the share of patents) that were classified as labor-saving. With this increase in innovation that threatened jobs came more resistance by the craft guilds. However, as the polity and the judiciary began to rule in favor of industry and entrepreneurs, there was a change in the form of resistance (Mokyr, 1990). Craft guilds started to resort to violence and industrial actions. These often violent actions, which took the form of riots, demonstrations and vandalism, became more frequent at the turn of the nineteenth century. Rather than being a sign of a strength, they were the death throes of a weakening guild system.

The debate concerning the impact of guilds on technology is bitter and mostly about whether guilds were categorically good or bad. The positivists claim that guilds fostered the diffusion of knowledge (Hickson and Thompson, 1991; Epstein, 1998, 2008; Richardson, 2004), whereas the negativists argue that guilds blocked technological progress (Ogilvie, 2008) ${ }^{17}$ The above discussion presents a more complex and nuanced picture. The attitude of guilds depended on their evolving nature, their concern with the impact of technology on their members, and the political and legal environment within which they operated. Although craft guilds were initially neither anti-competitive organizations nor hostile to technological change, they increasingly became so, especially when jobs were on the line. In the words of Mokyr (1997, p. 31), "most authorities are in agreement that eventually much of the guild system was overtaken by technologically reactionary forces which instead of protecting innovators threatened them".

\subsection{Spatial Competition, Resistance and Innovation}

How did the intensity of spatial competition affect the incentives and the ability of the craft guilds to block innovation? More to the point, is it possible to make sense of innovative activity and the diffusion of certain technologies based on the degree of spatial competition between cities? This question is at the heart of the theory put forth in this paper. In this subsection, we provide evidence that greater spatial competition was accompanied by less effective resistance by the craft guilds and by more innovative activity. Of course, both phenomena are interdependent: more innovation tends to be forthcoming in an environment where the discoverer expects less resistance.

Spatial competition and resistance. Spatial competition in England increased in the period leading up to the Industrial Revolution, through the growth in established cities, historical regional centers and ports, as well as through the emergence of new manufacturing towns, such as Manchester, Leeds, Birmingham and Sheffield.

\footnotetext{
${ }^{17}$ How one views guilds may of course depend on which institutions they are compared to. De la Croix, Doepke and Mokyr (2018) analyze the creation and transmission of knowledge under four institutions: the nuclear family, the clan, the guild and the market. They argue that guilds were superior to clans (though inferior to markets) and use this insight to explain why Western Europe experienced more growth than China in the pre-industrial period. In contrast, we compare guilds to markets on the eve of the Industrial Revolution, and argue that the decline of guilds led to a breakdown in resistance to labor-saving technologies.
} 
This increase in spatial competition came partly from the countryside and from unguilded towns. When faced with the growth of industry in rural areas and in new townships that were free of guilds, existing craft guilds often relaxed work rules ${ }^{18}$ However, the possibility of unguilded areas to industrialize was often limited by legal restrictions on the adoption of technology. For example, in the case of Kay's Fly Shuttle in the weaving of woolen cloth, 2\&3 Philip and Mary c. 11 stated that "no clothier might own more than one loom, not let out looms for hire outside of a city, borough, market town or corporate town."

Given the widespread existence of craft guilds, the increase in spatial competition and its relevance for industrialization came mostly from already guilded areas. In his study of the woolen industry in the West Riding and the West of England in the late $18^{\text {th }}$ century, Randall (1991) provides several examples where the diffusion of new technology occurred because of spatial competition between guilded regions. One such example concerns the introduction of the gig mill by the shearers for the purpose of finishing woolen cloth. According to Randall (1991), the shearers, which were among the best paid and strongest guilds in the woolen industry, were initially able to prevent the widespread use of the gig mill in the West of England for nearly two decades through legal appeals, violence and industrial actions. Resistance was weakest in Gloucester because the shearers there had previously used the gig mill for the purpose of finishing fine cloth and because its members were not inclined to pursue violent means to maintain the status quo. In contrast, the shearers in Wiltshire and Somerset were not opposed to the use of violence in preventing mill owners to introduce the gig mill. Not surprisingly, with lower potential costs to adopting, Gloucester mill owners in 1794 were the first to use the gig mill to finish rough cloth. Eventually, because of the spatial competition between the different regions, the shearers in Wiltshire and Somerset ended their resistance because they were losing business to the low-cost mills in Gloucester. These are the types of situations our theory addresses and the ones we focus on in this section 19

Spatial competition, of course, is not strictly an inter-city, intra-country phenomenon. The importance of spatial competition in reducing effective resistance to labor-saving technology is also apparent in situations where the spatial competition was international in nature. Randall (1991), for example, shows that resistance to the scribbling machine in the textile industry of the West

\footnotetext{
${ }^{18}$ According to Hibbert (1891, p. 129), "Most of the new industries did not come under the Apprenticeship Act [Statute of Artificers], and were consequently free and unshackled. Such formidable rivals drew away trade from the old privileged boroughs. The companies were quite unable to retain their monopolies." A similar phenomenon occurred on the continent. Ogilvie (2004) describes how Lille, a town in northern France, relaxed guild regulations in the textile industry in the late seventeenth century because of greater competition from rural weavers. The importance of competition between unguilded and guilded areas for industrialization is consistent with the model by Holmes and Schmitz (1995).

${ }^{19}$ Spatial competition between guilded cities was also important to understand technology adoption on the continent. For example, 't Hart (1993) and Mokyr (1998) describe how in 1604 the city government of Leiden in the Netherlands refused to support the craft guilds' pleas to ban a newly invented ribbon loom because it worried the industry would move to the nearby city of Delft, where guilds were weaker.
} 
of England ended in 1795 following a trade boom 20 The famous Luddite riots also coincided with changes in spatial competition. Binfield (2004) argues that mill workers associated with the Luddites only turned anti-technology after the British government cut off trade with France via the Prince Regent's Order in Council of 1811 in response to the Napoleonic War. Following the removal of this order in 1817, their resistance stopped and violence ended ${ }^{21}$ As mentioned before, the case of the Luddites shows that a pre-existence of a guild was not a necessary condition for resistance to occur. However, Randall (1991) provides evidence that having guilds facilitated resistance through the coordination of skilled workers.

To the extent that spatial competition made technology adoption more profitable, it also helped industry overcome workers' resistance, thus contributing to the decline of the craft guilds. Several examples illustrate the importance of profits to break resistance. One example relates to the finding of Randall (1991) that the guilds' success in blocking technology was mitigated by the size of firms. In particular, guild strikes over the introduction of gig mills and shearing frames were less effective against larger employers for the simple reason that larger factories were able to turn their mills into armed forces by hiring security personal.

Another example relates to the institutionalization of a state-sponsored local poor relief system that alleviated those displaced by new technology. By the early seventeenth century, the parishes were legally required to support their poor. This poor relief system was originally not created to help the losers from labor-saving technology (Greif and Iyigun 2013); instead, it was motivated by civic humanism (Slack, 1999). Over time, however, the role of poor relief in the co-evolution of technology and institutions became apparent. Sir F. M. Eden, a prominent social scientist of the eighteenth century, noted the importance of poor relief in mitigating opposition to labor-saving machinery 22 This more comprehensive approach to helping the poor was particularly pronounced in the newly industrialized areas in the North and the West (King, 2000). Moreover, as the system expanded, it became more predictable and better financed (Solar, 1995). The newly generated wealth and profits from industrialization and the local taxes paid on that wealth allowed for a continued increase in social spending, making it easier for society to compensate individuals whose inputs became redundant following the introduction of these technologies. In that way, increased profits from industrialization helped reduce resistance.

\footnotetext{
${ }^{20}$ In a different time and a different place, this echoes what happened to the US iron ore industry in the $1980 \mathrm{~s}$, when it experienced productivity gains in the face of increased international competition from Brazil (Schmitz, 2005).

${ }^{21}$ Wage concessions, abatement in food prices and military force were also contributing factors to ending the Luddite resistance according to Binfield (2004).

${ }^{22}$ In his 1797 seminal book on poverty he wrote that "machines or contrivances calculated to lessen labor ... throw many industrious individuals out of work; and thus create distresses that are sometimes exceedingly calamitous. Still, however, [the policy response to labor-saving inventions should] ... consider how far they [the inventions] actually do or do not promote the general wealth, by raising the largest quantity of provisions, or materials for manufacture, at the least cost, their inconvenience to individuals will be softened and mitigated, indeed, as far as it is practical" (Eden, 1797, vol. 1, p. xiv, cited in Greif and Iyigun, 2013, p. 534).
} 
Spatial competition and innovation. If, as the previous section suggests, resistance to new technologies broke down in regions characterized by strong spatial competition, then we should expect to see more innovative activity in such areas. To determine whether this is indeed the case, we undertake a systematic statistical analysis using the patent records of English counties in the period leading up to the Industrial Revolution. To measure the degree of innovative activity, we use patent data compiled by Bennet Woodcroft (1854), who became Superintendent of Specifications in the British Patent Office in 1852. Upon assuming this position, Woodcroft took up the task of documenting the number of patents for the previous two centuries. Due to his efforts, we have information on 4,212 patents at the county level from 1620 to $1823{ }^{23}$

To measure the degree of inter-city competition, we use a city's distance-weighted access to population in other cities, as captured by index $S_{2}^{r}{ }^{24}$ Since the data on innovation are for counties, we take the population-weighted average of $S_{2}^{r}$ at the county level. For counties with no cities, we set inter-city competition to zero. Our measures of spatial competition are for the years 1600 , 1700, 1750 and 1800. As there are no patent data for 1600, we restrict our county-level analysis to 1700, 1750 and 1800. For each one of these three years, we measure innovation by using a 20-year window. For example, for the year 1750, innovation in a county consists of the sum of patents in that county from 1740 to 1759 .

Table 2 reports regressions of total patents on average inter-city competition. The regressions are based on 38 counties and 3 time periods. Of course larger counties will on average have more patents. To account for this size effect, we control for a county's total urban population in all regressions. In addition, we always include time dummies to capture the increase in innovation over time. Since the dependent variable tends to be a relatively small whole number, we use estimation techniques appropriate for count data. Standard errors are clustered at the county level.

Column (1) uses a Poisson regression model, pooling the data for the three time periods. As expected, greater inter-city competition is found to be associated with more patents, with a coefficient that is statistically significant at the $5 \%$ level. As an alternative, Column (2) uses a negative binomial regression model. The result is qualitatively unchanged: higher inter-city competition implies more patents, with a coefficient statistically significant at the $1 \%$ level. Column (3) includes county fixed effects in a Poisson model. Again the results are similar and consistent with our story.

The final columns in Table 2 include a variable that reflects a city's average market size. It is calculated as the sum of the measure of inter-city competition, $S_{2}^{r}$, and the city's own population, $L^{r}$. As before, since our unit of observation is a county, we take the population-weighted average

\footnotetext{
${ }^{23}$ One caveat is that the patent data give the county of invention, rather than the county of adoption. For our analysis to be meaningful in the context of a model of technology adoption, there must be a positive correlation between a county's patent intensity and its propensity to introduce new technologies.

${ }^{24}$ As before, we follow the literature and set the distance decay parameter $\gamma$ equal to 1.5 , where distance is measured in kilometers.
} 
of market size across cities. We introduce $S_{2}^{r}+L^{r}$ as an additional regressor for two reasons. First, as discussed in the introduction, a city's market size is not the same as the inter-city competition it faces: the former includes the city's own population, whereas the latter does not. In that sense, our market size measure corresponds to the concept of market potential (Harris, 1954). Second, in our theory inter-city competition, and not market size, is what matters for industrialization. The ease to reach customers in other cities is the critical factor determining when resistance to technology breaks down.

Column (4) reports the results of a negative binomial regression and Column (5) reports the results for a Poisson regression. Both include separate measures for inter-city competition and market size, as well as county fixed effects. The coefficient on the spatial competition variable remains statistically significant with the right sign, whereas the coefficient on the market size variable is either statistically insignificant or has the wrong sign. This confirms the predictions of our theory: only spatial competition, and not market size, has a positive, statistically significant relation with innovation.

Table 2: Patents and Spatial Competition, English Counties, 1690-1809

\begin{tabular}{|c|c|c|c|c|c|}
\hline Dependent variable: & $\overline{(1)}$ & $\overline{(2)}$ & (3) & $\overline{(4)}$ & $\overline{(5)}$ \\
\hline \multirow[t]{2}{*}{ Patents } & Poisson & Negative & Poisson & Negative & Poisson \\
\hline & & Binomial & Fixed Effect & Binomial & Fixed Effect \\
\hline \multirow[t]{2}{*}{ City Spatial Competition } & $0.127^{* *}$ & $0.189^{* * *}$ & $0.063^{* *}$ & $0.186^{* * *}$ & $0.050 * *$ \\
\hline & {$[2.141]$} & {$[3.054]$} & {$[2.296]$} & {$[2.933]$} & {$[2.199]$} \\
\hline \multirow[t]{2}{*}{ City Market Size } & & & & -0.002 & $-0.003^{* * *}$ \\
\hline & & & & {$[-0.676]$} & {$[-4.307]$} \\
\hline \multirow[t]{2}{*}{ County Population } & $0.004^{* * *}$ & $0.006^{* * *}$ & -0.001 & $0.008^{* * *}$ & $0.003^{* * *}$ \\
\hline & {$[20.555]$} & {$[8.517]$} & {$[-1.123]$} & {$[2.664]$} & {$[2.828]$} \\
\hline Fixed Effects & No & No & Yes & No & Yes \\
\hline Time Dummies & Yes & Yes & Yes & Yes & Yes \\
\hline Pseudo R-square & 0.8493 & & 0.9585 & & 0.9592 \\
\hline Observations & 114 & 114 & 111 & 114 & 111 \\
\hline
\end{tabular}

\subsection{Summary}

The evidence above suggests that areas with stronger inter-city competition displayed weaker resistance and were more innovative. As England experienced a significant strengthening of inter-city competition between 1700 and 1800 (Table 1), a natural implication of these findings is that the craft guilds should have weakened over this period. This is indeed what occurred, and with guilds becoming less effective in blocking the introduction of labor-saving technology, it was only a matter of time before England industrialized and escaped its Malthusian trap. 
The empirical and historical evidence highlights four stylized facts that will be useful for our theory. First, there was a substantial increase in the degree of spatial competition in the time period preceding the Industrial Revolution. Second, the attempts of guilds to block the adoption of labor-saving technologies broadly coincided with that same time period. Third, the guilds' incentives and abilities to resist labor-saving technologies were weakened by the intensification of spatial competition. Fourth, compensating the losers from industrialization lessened the resistance to labor-saving technology, helped to maintain social order, and facilitated England's take-off.

\section{The Model}

Motivated by these stylized facts, we proceed to illustrate our theory in a static model in which resistance to process innovation depends on the economy's spatial organization. The basic setup of the model borrows from Desmet and Parente (2010), with two important differences. First, we allow for the existence of city-industry guilds that can dictate technology use in their city and industry. Second, we allow for a continuum of industries, rather than for just one industry. This implies that any given guild has power over only a specific industry in a city, rather than over a city's entire economy.

We proceed in three steps. First, we describe the model economy and characterize the equilibrium conditions when the only technology available is an artisanal one that requires skilled labor. Second, we introduce a modern technology that does not require the skilled labor input of the artisanal technology, and characterize the equilibrium conditions for which guilds - organizations of skilled workers in an industry and city — form to block the use of the modern technology 25 Third, we show analytically that if trade is prohibitively costly between cities, guilds never give up resisting and the artisanal technology is used forever. An important corollary of this result is that inter-city trade is necessary for the modern technology to be adopted.

\subsection{Artisanal Technology Only}

The model consists of two identical city-regions, referred to as the East (E) and the West (W) and indexed by the superscript $r \in\{W, E\}$. Each city-region produces a non-tradeable agricultural good, using unskilled labor, and a continuum of measure one of tradeable industrial goods, using skilled labor. For each type of industrial good, monopolistically competitive firms produce a number of varieties. Goods can be thought of as textiles, furniture, wines, etc., whereas varieties correspond to different colors, flavors or textures of these goods. We use $i \in[0,1]$ to denote a particular industrial good, $v_{i}$ to denote a particular variety of that good $i, V_{i}$ to denote the set of varieties of

\footnotetext{
${ }^{25}$ Although skills or human capital are found by Barro (1991) to have been important for economic growth and technological change in the post-World War II period, they seem to have been less crucial in the early stages of the first Industrial Revolution. Indeed, with the switch from artisanal workshops to factories during this period, skilled labor became less critical to the production process.
} 
good $i$ produced in the entire economy, and $V_{i}^{r}$ to denote the set of varieties of good $i$ produced in city-region $r$.

Each city-region is populated by a continuum of measure $L$ of one-period lived households, of which measure $(1-\mu) L$ are skilled and measure $\mu L$ are unskilled. We denote a household's type by the superscript $h \in\{u, s\}$, where $u$ refers to unskilled and $s$ to skilled. Each household inelastically supplies one unit of labor to the region where it resides. There is no household migration between city-regions.

\subsubsection{Preferences and Utility Maximization}

Preferences. Household preferences are defined over an agricultural good and a continuum of industrial goods. Preferences over each industrial good is of the Hotelling-Lancaster type, meaning that a household's location on the unit circle identifies the particular variety of each good that it prefers over all others. Households of each type and each city-region are uniformly distributed around the unit circle. Let $d_{v_{i} \tilde{v}}$ denote the shortest arc distance between variety $v_{i}$ and the household's ideal variety $\tilde{v}$ for a given good $i{ }^{26}$ The utility that a household of type $h$, residing in city-region $r$ and located at point $\tilde{v}$ on the unit circle, derives from consuming $c_{a}^{r h}$ units of the agricultural good and $c_{v_{i}}^{r h}$ units of variety $v$ of good $i$ is given by

$$
(1-\alpha) \log c_{a}^{r h}+\alpha \int_{0}^{1} \log f\left(c_{v_{i}}^{r h} \mid v_{i} \in V_{i}\right) d i
$$

where, following Hummels and Lugovskyy (2009),

$$
f\left(c_{v_{i}}^{r h} \mid v_{i} \in V_{i}\right)=\max _{v_{i} \in V_{i}}\left(\frac{c_{v_{i}}^{r h}}{1+d_{v_{i} \tilde{v}}^{\beta}}\right) .
$$

In expression (5), the denominator $1+d_{v_{i}}^{\beta}$, where $\beta>0$, is the quantity of variety $v_{i}$ that gives the household the same utility as one unit of its ideal variety $\tilde{v}$. In the literature, this term is referred to as the Lancaster compensation function.

Utility maximization. The utility function (5) implies that a household residing in city-region $r$ buys a single variety $\hat{v}_{i}^{r}$ that minimizes the cost of the quantity equivalent to one unit of its ideal variety, $\tilde{v}$ :

$$
\hat{v}_{i}^{r}=\operatorname{argmin}\left[p_{v_{i}}^{r}\left(1+d_{v_{i} \tilde{v}}^{\beta}\right) \mid v_{i} \in V_{i}\right]
$$

where $p_{v_{i}}^{r}$ is the price of variety $v_{i}$ in city-region $r$. Let $y^{r h}$ be the income of a household of type $h$ residing in city-region $r$. The household's budget constraint is then

$$
p_{a}^{r} c_{a}^{r h}+\int_{0}^{1}\left(\sum_{v_{i} \in V_{i}} p_{v_{i}}^{r} c_{v_{i}}^{r h}\right) d i \leq y^{r h} .
$$

\footnotetext{
${ }^{26}$ Since a household's ideal variety depends on its location on the unit circle, $\tilde{v}$ does not require a subscript $i$.
} 
Maximizing (4) subject to (7) implies that a household of type $h$ residing in $r$ with ideal variety $\tilde{v}$ spends fraction $(1-\alpha)$ of his income on the agricultural good, and fraction $\alpha$ on the industrial goods, namely,

$$
p_{a}^{r} c_{a}^{r h}=(1-\alpha) y^{r h}
$$

and

$$
p_{\hat{v}_{i}^{r}}^{r} c_{\hat{v}_{i}^{r}}^{r h}=\alpha y^{r h}
$$

\subsubsection{Technologies and Profit Maximization}

Farms. The farm sector is perfectly competitive and produces a homogeneous good according to a linear technology that uses unskilled labor only. Without loss of generality, we assume the farm good is non-tradeable. Let $Q_{a}^{r}$ denote farm output in city-region $r$. Then

$$
Q_{a}^{r}=\Gamma_{a} L_{a}^{r}
$$

where $\Gamma_{a}$ is farm-sector TFP and $L_{a}^{r}$ is farm-sector employment in city-region $r$.

As farm TFP is by assumption identical in both city-regions, the agricultural good's price in each region can be normalized to 1 , i.e., $p_{a}^{r}=1$. Profit maximization then implies a common agricultural wage rate in both regions given by

$$
w_{a}=\Gamma_{a} .
$$

Industries. Each industry $i \in[0,1]$ in each city-region produces a set of differentiated varieties, which are tradeable across regions. Trade is subject to iceberg transport costs: to deliver one unit of a variety produced in one city-region to the other city-region, $\tau \geq 1$ units must be shipped. The market structure in any given industry is monopolistically competitive due to the existence of a fixed operating cost. Output is generated using an artisanal production technology, the key property of which is that it requires skilled labor to operate. Let $Q_{v_{i}}^{r}$ denote the output of a firm in city-region $r$ that produces variety $v_{i}$. Then, the artisanal technology is

$$
Q_{v_{i}}^{r}=\Gamma_{v}\left[L_{v_{i}}^{r}-\kappa\right]
$$

where $\kappa$ is the fixed operating cost in units of labor, $L_{v_{i}}^{r}$ is the total input of skilled workers, and $\Gamma_{v}$ is the marginal product.

When maximizing profits, each monopolist takes the choices of other firms as given. In the interest of space, we only present the profit maximization problem facing a firm located in the East; expressions for Western firms can be derived analogously. To distinguish between the production and the consumption locations, we use a double superscript, where the first superscript refers to the production location and the second refers to the consumption location. 
Using the production function (12), together with the fact that the Eastern firm's production meets consumption of both Eastern and Western consumers, namely,

$$
Q_{v_{i}}^{E}=C_{v_{i}}^{E E}+\tau C_{v_{i}}^{E W}
$$

we can write an Eastern firm's profits, $\Pi_{v_{i}}^{E}$, as

$$
\Pi_{v_{i}}^{E}=p_{v_{i}}^{E E} C_{v_{i}}^{E E}+p_{v_{i}}^{E W} C_{v_{i}}^{E W}-w_{x}^{E}\left[\kappa+\frac{C_{v_{i}}^{E E}+\tau C_{v_{i}}^{E W}}{\Gamma_{v}}\right],
$$

where $p_{v_{i}}^{E E}, p_{v_{i}}^{E W}, C_{v_{i}}^{E E}$ and $C_{v_{i}}^{E W}$ are the prices and consumption levels of an Eastern-produced variety in the Eastern and the Western markets, and $w_{x}^{E}$ is the Eastern wage rate in the industrial sector.

An Eastern firm producing variety $v_{i}$ chooses the price in the East, $p_{v_{i}}^{E E}$, and the price in the West, $p_{v_{i}}^{E W}$, to maximize (14), subject to demand in the East and demand in the West, taking the wage rate in the industrial sector, $w_{x}^{E}$, as given. The profit-maximizing price in each market is the usual mark-up over the marginal unit cost, so that

$$
p_{v_{i}}^{E E}=\frac{w_{x}^{E}}{\Gamma_{v}} \frac{\varepsilon_{v_{i}}^{E E}}{\varepsilon_{v_{i}}^{E E}-1}
$$

and

$$
\frac{p_{v_{i}}^{E W}}{\tau}=\frac{w_{x}^{E}}{\Gamma_{v}} \frac{\varepsilon_{v_{i}}^{E W}}{\varepsilon_{v_{i}}^{E W}-1},
$$

where $\varepsilon_{v_{i}}^{E E}$ and $\varepsilon_{v_{i}}^{E W}$ are the price elasticities of demand for variety $v_{i}$ in the East and the West. Namely,

$$
\varepsilon_{v_{i}}^{E E}=-\frac{\partial C_{v_{i}}^{E E}}{\partial p_{v_{i}}^{E E}} \frac{p_{v_{i}}^{E E}}{C_{v_{i}}^{E E}}
$$

and

$$
\varepsilon_{v_{i}}^{E W}=-\frac{\partial C_{v_{i}}^{E W}}{\partial p_{v_{i}}^{E W}} \frac{p_{v_{i}}^{E W}}{C_{v_{i}}^{E W}} .
$$

\subsubsection{Aggregate Demands}

We now derive the aggregate demands for the agricultural good and for each differentiated industrial good. As our analysis focuses exclusively on the properties of the model's symmetric Nash equilibria, our derivations are done in this context. In particular, we characterize the aggregate demands when all firms in each industry are equally spaced around the unit circle, and are alternating in the sense that an Eastern firm's nearest competitors on its right and on its left on the unit circle are Western firms.

Agricultural good. By assumption, there is no inter-city trade in the agricultural good, and so the demand faced by farms in a given city-region is derived exclusively from its own residents. ${ }^{27}$

\footnotetext{
${ }^{27}$ Strictly speaking, this assumption is not necessary since in a symmetric equilibrium each region would consume its own production of the agricultural good.
} 
Since each household spends a fraction $1-\alpha$ of its income on the agricultural good, the aggregate demand in city-region $r$ is

$$
C_{a}^{r}=(1-\alpha)\left((1-\mu) y^{r s}+\mu y^{r u}\right) L
$$

Differentiated industrial goods. As differentiated industrial goods are tradeable, the demand for any firm's variety will have an own city-region component and an other city-region component. Because each household buys a single variety of each industrial good and spends a fraction $\alpha$ of its income on it, we only need to determine the measure of households in each region that buys a given variety $i$ in order to determine the two regional components of the firm's aggregate demand. With all varieties being equally spaced around the unit circle in a symmetric equilibrium, aggregate demand for an Eastern firm producing variety $v^{E}$ depends on the locations and the prices of its closest neighbors to its right and to its left on the unit circle, each of which is a Western firm. ${ }^{28}$ Since these two Western competitors are each located at the same distance $d$ from the Easternproduced variety, we do not need to differentiate between the Western competitors, and therefore denote each by $v^{W}$.

To derive each component of aggregate demand for variety $v^{E}$, it is critical to identify the household who is indifferent between buying varieties $v^{E}$ and $v^{W}$. The indifferent Eastern household is the one located at distance $d^{E E}$ from $v^{E}$, where $d^{E E}$ satisfies

$$
p^{W E}\left[1+\left(d-d^{E E}\right)^{\beta}\right]=p^{E E}\left[1+\left(d^{E E}\right)^{\beta}\right]
$$

Given this indifference condition applies to Eastern households both to the right and to the left of $v^{E}$, a share $2 d^{E E}$ consumes variety $v^{E}$. As both skilled and unskilled Eastern households are uniformly distributed along the unit circle and each household spends a share $\alpha$ of its wage earnings on a single variety in any given industry, the total demand for $v^{E}$ emanating from Eastern households is

$$
C^{E E}=\frac{2 d^{E E} \alpha\left[(1-\mu) y^{E s}+\mu y^{E u}\right] L}{p^{E E}} .
$$

By analogy we can derive the West's total demand for $v^{E}$,

$$
C^{E W}=\frac{2 d^{E W} \alpha\left[(1-\mu) y^{W s}+\mu y^{W u}\right] L}{p^{E W}},
$$

where $d^{E W}$ is the distance from $v^{E}$ at which a Western household is indifferent between consuming $v^{E}$ or $v^{W}$, so that

$$
p^{W W}\left[1+\left(d-d^{E W}\right)^{\beta}\right]=p^{E W}\left[1+\left(d^{E W}\right)^{\beta}\right]
$$

\footnotetext{
${ }^{28}$ Depending on the parameter values, aggregate demand could in principle also depend on the locations and the prices of varieties that are farther away on the unit circle. However, in the numerical section parameter values are such that only the closest neighbors matter, so we write down our theory for this simple case.
} 
Price elasticity. With these equations in hand, we can solve for the price elasticities of demand that determine the mark-ups in the firm's optimal pricing decisions $(15)$ and (16). The first step is to differentiate 19 with respect to $p^{E E}$ to arrive at the following relation

$$
-\frac{\partial C^{E E}}{\partial p^{E E}} \frac{p^{E E}}{C^{E E}}=1-\frac{\partial d^{E E}}{\partial p^{E E}} \frac{p^{E E}}{d^{E E}}
$$

Next, we solve for the partial derivative, $\partial d^{E E} / \partial p^{E E}$, by taking the total derivative of the indifference equation (18) with respect to $p^{E E}$. Using this result, we obtain

$$
\varepsilon^{E E}=1+\frac{\left[1+\left(d^{E E}\right)^{\beta}\right] p^{E E}}{\left[p^{E E} \beta\left(d^{E E}\right)^{\beta-1}+p^{W E} \beta\left(d-d^{E E}\right)^{\beta-1}\right] d^{E E}} .
$$

By analogy, the elasticity faced by an Eastern firm emanating from the West is

$$
\varepsilon^{E W}=1+\frac{\left[1+\left(d^{E W}\right)^{\beta}\right] p^{E W}}{\left[p^{E W} \beta\left(d^{E W}\right)^{\beta-1}+p^{W W} \beta\left(d-d^{E W}\right)^{\beta-1}\right) d^{E W}} .
$$

\subsubsection{Equilibrium Conditions}

In addition to utility maximization and profit maximization, all markets must clear in equilibrium and profits in each industry must be zero on account of entry being free.

Goods and labor market clearing. The market clearing conditions for each of the goods is straightforward. For each industrial differentiated variety, the output of the firm must equal the demand from its own city-region customers plus the demand from the other city-region's customers adjusted for the iceberg cost, namely, (13). The corresponding condition for the agricultural market is

$$
\Gamma_{a} L_{a}^{r}=C_{a}^{r}
$$

The labor markets must also clear in each region. As only skilled labor is used in the artisanal technology, and only unskilled labor in farming, there are two labor markets in each region. The supply side of each market is straightforward, provided that the industrial wage is greater than the agricultural one. In this case, the supply of workers in the unskilled labor market is simply the measure of unskilled households, $\mu L$, and the supply of workers in the skilled labor market is the measure of skilled households, $(1-\mu) L$. The demand side of the unskilled labor market is total agricultural production divided by worker productivity, $C_{a}^{W} / \Gamma_{a}$. For skilled labor, as $d$ is the shortest-arc distance between any two varieties on the unit circle, it follows that the number of varieties of each industrial good produced in the economy is $1 / d$, with each city-region producing $1 /(2 d)$ varieties. Given the production function $\left[12\right.$, each Eastern firm employs $\kappa+\frac{C^{E E}+\tau C^{E W}}{\Gamma}$ units of skilled labor. Thus, provided $w_{x}>w_{a}$, the labor market clearing conditions are:

$$
\begin{aligned}
(1-\mu) L & =\frac{1}{2 d}\left[\kappa+\frac{C^{E E}+\tau C^{E W}}{\Gamma_{v}}\right] \\
\mu L & =\frac{C_{a}^{E}}{\Gamma_{a}} .
\end{aligned}
$$


Zero profit condition. Because of free entry and exit, all firms make zero profits. For Eastern firms in any given industry $i$ this implies

$$
p^{E E} C^{E E}+p^{E W} C^{E W}-w_{x}^{E}\left[\kappa+\frac{C^{E E}+\tau C^{E W}}{\Gamma}\right]=0 .
$$

The zero profit condition is important because it determines the number of varieties produced in the East, which in turn determines the price elasticities of demand. It also implies that a household's income is equal to its wage, so that

$$
\begin{aligned}
& y^{r s}=w_{x}^{r} \\
& y^{r u}=w_{a}^{r} .
\end{aligned}
$$

We are now ready to define a symmetric equilibrium of the economy.

Definition of Symmetric Artisanal Equilibrium. An Artisanal Technology Symmetric Equilibrium (ARTSE) is a vector of elements $\left(p^{i i *}, \varepsilon^{i i *}, p^{i j *}, \varepsilon^{i j *}, w_{x}^{i *}, w_{a}^{i *}, d^{*}, d^{i i *}, d^{i j *}, Q^{i *}, Q_{a}^{i *}, C^{i i *}\right.$, $\left.C^{i j *}, C_{a}^{i *}, V^{i *}\right)$, where $i, j \in\{E, W\}, i \neq j$, with $x^{i i *}=x^{j j *}, x^{i j *}=x^{j i *}$ and $x^{i *}=x^{j *}$ for any variable $x^{*}$, that satisfies conditions (10), (11), (13), (15), (16), 117), (18), (19), (20), (21), (23), (24), (25), 26), 27) and (28), as well as the corresponding conditions for Western industrial firms.

\subsection{Innovation, Guilds and Spatial Competition}

We now assume that a modern technology becomes available. Compared to the artisanal technology, it has the advantage of a higher marginal productivity, but the drawback of a higher fixed cost. In addition, operating the modern technology does not require skilled labor. As a result, the skilled workers in an industry may experience a reduction in earnings because of competition from unskilled labor if a firm decides to switch to the modern technology.

The starting point of this analysis is the ARTSE, i.e., the symmetric equilibrium where all firms use the artisanal technology. We seek to understand the incentives of firms in a given industry and city-region to adopt the modern technology, and the incentives of skilled workers in that industry and city-region to resist its adoption.

We proceed in three steps. First, we describe conditions for which an individual firm in a city-region finds it profitable to adopt the modern technology. Then we identify conditions for which the skilled workers in an industry and city-region form a guild to prevent the switch to the modern technology. Guilds, if they form, do so at the level of the industry and city, rather than at the level of the firm or at the level of both cities. By organizing in a guild, the workers in a given industry and city are able to prevent any firm in its industry and its city from adopting the modern technology unless they are compensated. Finally, we establish conditions for an industry in a cityregion to buy out guild members so they stop blocking adoption. In doing so, we seek to highlight 
the relation between the degree of spatial competition and the existence of technology-blocking institutions.

\subsubsection{Incentive to Adopt Modern Technology}

We start by studying the problem of an individual firm in a single industry and city that switches to the modern technology. By switching, the output of a firm in city-region $r$ that produces variety $v_{i}$ is given by the following production process

$$
Q_{v_{i}}^{r}=\Gamma_{v}^{r}(1+\gamma)\left[L_{v_{i}}^{r}-\kappa-\phi\right]
$$

where $\phi>0$ is the increase in the fixed operating cost and $\gamma>0$ is the proportional improvement in the marginal productivity, compared to the artisanal technology

In establishing the condition for a single firm to adopt the modern technology, we assume that all other firms in the economy continue to use the artisanal technology. Effectively, we analyze the incentives of a single Eastern firm to deviate from the ARTSE; analogous expressions for a Western firm can easily be derived. For exposition, we use the prime symbol (') to denote variables that pertain to deviations from the ARTSE. Let $\Pi^{E \prime}$ denote the profit of a single Eastern firm deviating from the artisanal technology. A firm will deviate and switch to the modern technology if

$$
\begin{array}{ll}
\Pi^{E \prime}>0, & \text { where } \\
& \Pi^{E \prime}=\max _{p^{E E^{\prime}}, p^{E W^{\prime}}}\left\{p^{E E^{\prime}} C^{E E^{\prime}}+p^{E W^{\prime}} C^{E W \prime}-w_{a}\left[\kappa+\phi+\frac{C^{E E \prime}+\tau C^{E W \prime}}{\Gamma_{v}(1+\gamma)}\right]\right\} \\
\text { s.t. } \quad & C^{E E \prime}=\frac{2 d^{E{ }^{E \prime}} \alpha\left[(1-\mu) w_{x}^{E}+\mu w_{a}^{E}\right] L}{p^{E E \prime}} \\
& C^{E W \prime}=\frac{2 d^{E W \prime} \alpha\left[(1-\mu) w_{x}^{W}+\mu w_{a}^{W}\right] L}{p^{E W \prime}} .
\end{array}
$$

Notice that because a firm can hire any worker if it uses the modern technology, the relevant wage bill is evaluated at $w_{a}$, since restrictions on parameters guarantee that $w_{a}<w_{x}^{r}$ in the ARTSE.

Deriving the profit-maximizing prices for a deviating firm follows the outline in Section 3.1.3. We start with the conditions that identify the Eastern household and the Western household that are indifferent between the deviating firm's variety and its neighbors' varieties to the left and to the right,

$$
p^{W E}\left[1+\left(d-d^{E E \prime}\right)^{\beta}\right]=p^{E E \prime}\left[1+\left(d^{E E \prime}\right)^{\beta}\right]
$$

and

$$
p^{W W}\left[1+\left(d-d^{E W^{\prime}}\right)^{\beta}\right]=p^{E W^{\prime}}\left[1+\left(d^{E W \prime}\right)^{\beta}\right] .
$$

\footnotetext{
${ }^{29}$ Note that the fact that the modern technology does not require skilled workers applies to both the fixed and the variable workers.
} 
Using the relation between the price elasticity of demand and the price elasticity of distance on the unit circle given by (22), and differentiating each of these equations separately with respect to the firm's pricing choice, we arrive at expressions of the price elasticity of demand of a deviating Eastern firm in both the Eastern market and Western market. These are

$$
\varepsilon^{E E \prime}=1+\frac{\left[1+\left(d^{E E \prime}\right)^{\beta}\right] p^{E E \prime}}{\left[p^{E E \prime} \beta\left(d^{E E \prime}\right)^{\beta-1}+p^{W E} \beta\left(d-d^{E E \prime}\right)^{\beta-1}\right] d^{E E \prime}}
$$

and

$$
\varepsilon^{E W \prime}=1+\frac{\left[1+\left(d^{E W \prime}\right)^{\beta}\right] p^{E W \prime}}{\left[p^{E W \prime} \beta\left(d^{E W \prime}\right)^{\beta-1}+p^{W W} \beta\left(d-d^{E W \prime}\right)^{\beta-1}\right) d^{E W \prime}} .
$$

For the subsequent analysis it is important to point out that the deviation condition (30) is the same whether we consider one firm in a particular industry and city-region deviating or whether we consider all firms in that industry and city-region deviating. There are two reasons for this result. First, the incentive for an Eastern firm to deviate only depends on its two Westernproduced neighboring varieties, and second, each industry is measure zero, so that even if all firms in a given industry and city-region were to deviate there would be no effect on aggregate income.

When are firms more likely to deviate and adopt the modern technology? The following claim states that larger cities, lower transport costs and shorter inter-city distances increase the profitability of deviating. Hence, larger markets, whether coming from the growth in city size or the increase in inter-city competition, incentivize firms to switch to the modern technology.

Claim 1. Starting off in an equilibrium where all firms use the artisanal technology, a larger population, $L$, or a lower iceberg cost, $\tau$, increases the incentives of an individual firm to switch to the modern technology.

Here we limit ourselves to providing some intuition for this claim rather than providing a formal proof. As shown in Desmet and Parente (2010) for the case of an increase in population, the Hotelling-Lancaster preference construct implies a less-than-proportional increase in the number of varieties, and therefore an increase in firm size. This is in contrast to the more commonly used Spence-Dixit-Stiglitz construct where the number of varieties increases proportionally with population, leaving firm size unchanged. With Hotelling-Lancaster preferences, this increase is less than proportional because the product space is bounded and each household has an ideal variety given by its location on the unit circle. As the number of varieties increases, neighboring varieties become more substitutable, leading to an increase in the price elasticity of demand. This implies a drop in mark-ups, so that each differentiated good producer must become larger to break even. This increase in firm size favors adoption, since a firm can now spread the fixed adoption cost of the modern technology, $\phi$, over more units. The deviation condition (30) is thus more likely to be satisfied for larger city-regions.

A drop in transport costs has a similar effect on the incentives to adopt the modern technology, as it too leads to greater competition between neighboring varieties, and thus to lower 
mark-ups and larger firms 30 It is important to note that decreasing the geographic distance between city-regions is equivalent to lowering transport costs. Hence, having city-regions more closely spaced also increases the incentive for firms to switch to the modern technology.

\subsubsection{Guilds}

While producers' incentives to adopt the modern labor-saving technology are driven by market size, we will now show that the skilled workers' incentives to accommodate this technological shift depends on inter-city or spatial competition. To that end, we turn to analyzing the decision of skilled workers in an industry and city-region to form a professional guild for the purpose of blocking the introduction of the modern technology. Of course, as already discussed, there are other reasons why in reality guilds might have formed in the first place, but they are not considered here. Thus, the question this paper addresses is: if skilled workers in a given industry and city-region did not form a guild earlier for some other reason, would they have an incentive to do so with the objective of resisting the adoption of the modern technology? Equivalently, if skilled workers already formed a guild for some other purpose, when would that guild turn anti-technology?

The starting point for our formal analysis is, again, the symmetric equilibrium where only the artisanal technology is available. Starting with the number of skilled workers employed in a given industry and city-region, we consider their decision to form a guild for the sole purpose of preventing the introduction of the modern technology. A guild is specific to an industry and a city-region. By this we mean that if, for example, a guild forms in industry $i$ in the East, it has no power over the choices of Western firms in their industry. The guild's power is absolute in that no firm in the guild's industry and city-region can switch to the modern technology unless guild members are completely compensated for any reduction in earnings. If the earnings of skilled workers can be maintained at the level in the ARTSE, the modern technology gets adopted, and the guild disbands, as it no longer has a reason to exist.

We consider an arbitrary industry $i$ in the East. A group of skilled workers in industry $i$ in the East will form a guild if at least one firm finds it profitable to use the modern technology and if the industry profits, were all firms to adopt, are too small to compensate skilled workers for lost wages 31 The first condition is simply the deviation condition 30. Clearly, if the first condition is not met, then no industry will have a guild for the simple reason that skilled workers are not at risk of earning lower wages. The second condition says that the profits from adoption are not enough to compensate the skilled workers, so that

$$
\frac{V_{i}^{E *} \Pi_{i}^{E^{\prime}}}{G_{i}^{E *}}+w_{a}^{E *} \leq w_{x}^{E *}
$$

\footnotetext{
${ }^{30}$ In contrast to an increase in population, a decrease in iceberg costs actually leads to a decrease in the number of varieties produced by each region. Nevertheless, the price elasticity of demand still increases on account of the greater competition from producers of the other region.

${ }^{31}$ From our discussion before, recall that the condition for one firm to deviate or for all firms to deviate is the same.
} 
where $G_{i}^{r}$ denotes the size of the guild in industry $i$ and city-region $r$. As there is measure $L$ of workers in each region, of which $1-\mu$ are skilled, and measure one of industries in each region, then the size of a guild that forms in industry $i$ and city-region $r$ is $(1-\mu) L$.

Notice that (35) makes two implicit assumptions about how losers are compensated. First, the transfers to the skilled workers are financed by the profits of the industry that switches to the modern technology. This compensation mechanism could be interpreted as being the outcome of either a bargaining process between the industry and the guild or a tax on industry profits. The latter interpretation is not unlike the poor laws which were financed locally by taxes on the wealthy 3233 Second, there are no labor market frictions in the sense that displaced skilled workers can immediately find employment as unskilled workers in the economy 34 If we were to allow for the possibility of unemployment, the existence of poor relief would become even more important, as the expected income of the skilled workers would fall below that of the unskilled.

When profits from innovating are positive but too small to fully compensate the losers, there is a symmetric equilibrium in which all prices and allocations correspond to those associated with the ARTSE, but where each industry in each city-region has a guild that blocks the use of the modern technology. In effect, the set of skilled workers in each industry and city-region, by forming a guild, are able to sustain the same equilibrium allocations and prices as before. We refer to this equilibrium as a Symmetric Artisanal Equilibrium with Guilds (GARTSE). Formally,

Definition of Symmetric Artisanal Equilibrium with Guilds. A Symmetric Artisanal Equilibrium with Guilds (GARTSE) satisfies the same conditions as ARTSE, with two differences: (i) the deviation condition (30) is satisfied, and (ii) the profits of a deviating industry in a city-region are not enough to pay off their skilled workers, i.e., (35) is satisfied.

In light of Claim 1, one would expect guilds to form when market size reaches a certain threshold and disband when it reaches a second higher threshold. The second part of this statement is not correct, however. As we now show, an increase in market size, $L$, is by itself not enough for guilds to disappear. Instead, what is critical is the spatial distribution of city-regions: only with sufficient inter-city competition will the guilds disband. Hence, while the first threshold depends on market size, the second threshold depends on inter-city competition.

\footnotetext{
${ }^{32}$ Strictly speaking, in our model the deviating industry would be the only one making profits, so that the limit on tax revenues from profits would be total profits, as in 35 .

${ }^{33}$ As a practical matter, resistance could also be overcome through the polity or the judiciary. If one assumes that this only occurs successfully if industry profits from adoption are big enough, either because industries need to lobby or because the polity becomes more favorable to adoption when the gains are large, then the results regarding the relation between spatial competition and innovation would be qualitatively unchanged. However, to keep things simple, we do not consider this alternative here.

${ }^{34}$ However, we assume that they cannot be employed in other industries.
} 


\subsection{Market Size, Spatial Competition and the Demise of Guilds}

In this section we show that the degree of spatial competition determines the point at which the skilled workers end their resistance to the modern technology so that the economy can take off. Importantly, we show that in the absence of trade between cities, an increase in market size, $L$, is never enough to lead to the demise of guilds, although it is sufficient to bring about their formation. Trade between cities is, hence, essential for an economy's take-off. The intuition for this result is as follows. Suppose the economy is in a symmetric artisanal equilibrium with guilds (GARTSE). For the guilds to disappear, the industry's profits from deviating must be enough to compensate the industry's original skilled workers. These profits come from increasing market share at the expense of other firms in the industry. When there is trade, the industry in one city-region can increase its market share at the expense of the other city-region; however, in the absence of trade, this is not possible, so that deviating never leads to a sufficient increase in profits to compensate the original workers. We now formally state and prove this proposition.

Proposition 1. For an economy in GARTSE that faces prohibitive trade costs, an increase in own city-region population will never lead to the violation of (35), so that guilds will never disband.

Proof. Start from an equilibrium where all firms use the artisanal technology. Firms make zero profits and all the firms' earnings are paid out to the industry's (skilled) workers. Now suppose all those firms switch to the modern technology. Because each industry is measure zero and household preferences are Cobb-Douglas across industries, the total income spent on a given industry's varieties is independent of the technology it uses. Hence, switching technologies does not affect an industry's total earnings.

Because the number of firms in the adopting industry is kept constant, the price elasticity of demand does not change, so that mark-ups remain unchanged. With Cobb-Douglas preferences between different industrial goods and $w_{a}<w_{x}$, the drop in the price resulting from adoption is greater than the increase in the marginal productivity. As a result, the number of variable (and total) workers employed in the adopting industry increases. Since all of the industry's revenues before the technology switch were going to the industry's original workers, and since the industry's revenues have not changed with the adoption of the modern technology, it is impossible to make all those original workers better off because the number of workers the industry employs has gone up. Hence, (35) is never violated, and guilds never disband.

This proposition suggests a fundamental asymmetry between the incentives of producers to adopt the modern technology and the incentives of craftsmen to accept industrialization. Whereas inter-city competition determines both the incentives of producers and craft guilds to industrialize,

market size by itself only affects the producers' returns to industrialization. As a result, an increase in market size without an accompanying strengthening of inter-city competition does not suffice for 
an economy to take off. Market-size theories of the Industrial Revolution are therefore incomplete, and may lead to erroneous conclusions.

The above proposition assumes that trade costs between city-regions are prohibitive. Once we allow for trade, an increase in market size may be accompanied by an increase in inter-city competition. For example, if both city-regions grow in size, then each city-industry gains access to more consumers, both locally and in the other city-region. In that case, market size increases and inter-city competition strengthens, making economic take-off more likely. This does not change the main insight of Proposition 1 though: it is a city-industry's greater access to consumers in the other city-region, rather than in the own city-region, that increases its incentives to innovate. Hence, what matters for economic take-off is the increase in inter-city competition, rather than the greater market size by itself.

The assumption that guilds operate at the city-region level rather than at the national level is key to understanding the role of inter-city trade. Consistent with historical evidence, in the model a guild's power does not transcend the boundaries of its own city-region. As a result, in a multi-city model, when an industry in a given city switches to the new technology, it only needs to compensate the skilled workers it originally employed in its own city. This it can do by capturing market share from firms in the other cities. This possibility of capturing market share between cities is greater when inter-city competition intensifies.

The proof of Proposition 1 depends partly on industries being small and on the elasticity of substitution between industries being one. If industries were large or the elasticity of substitution between industries were greater than one, then innovation by a local industry would generate a general equilibrium effect that expands the own city-region's market, hence changing the incentives to adopt the modern technology. However, these alternative assumptions would, once again, not change the main qualitative insight: spatial competition is more powerful in breaking down resistance to innovation than market size.

\section{Calibration}

To assess the plausibility of our theory we calibrate the model economy to the evolution of spatial competition in England between 1400 and 1600 and derive the model's predictions for England's take-off taking into account the post-1600 evolution of spatial competition there. The first model period, without loss of generality, is associated with the year 1400, and the model period when skilled artisans first organize for the purpose of blocking the modern technology is associated with the year 1600. As discussed in Section 2, although guilds appeared much earlier in Europe, it is not until the seventeenth and eighteenth centuries that they regularly exhibited resistance to labor-saving technology. Since in our theory craft guilds have the single function of blocking the introduction of labor-saving technology, the relevant starting date for the calibration is when guilds began resisting, not when they first appeared. This explains our choice of 1600 . 
The calibration exercise is done assuming that the modern technology is already available in 1400. This is a slight and inconsequential modification from the theoretical analysis above, which assumes that only the artisanal technology is available originally ${ }^{35}$ Given the evolution of spatial competition in England between 1400 and 1600, the parameter values are assigned so that the profits of a firm in any industry and city that introduces the modern technology are (i) negative prior to 1600 and (ii) positive but insufficient to compensate skilled workers for lost earnings in 1600. In terms of the equilibrium concepts, this means that between 1400 and 1600, the ARTSE prevails and in 1600 the GARTSE exists.

The test of the theory then involves determining the first date when the GARTSE fails to exist. At this date industry profits in a given city are large enough to compensate the skilled workers in that industry for their reduced earnings, so that guilds stop resisting, and the economy takes off. To determine this date, we feed data on English city sizes and inter-city distances in the post-1600 period into the calibrated model and check when (35), the second condition for the guilds to exist, ceases to hold. As we will show, the calibrated model predicts fairly closely the date at which guilds ended their resistance to labor-saving technology in England.

\subsection{Parametrization}

Table 3: Parameter Values

\begin{tabular}{ll}
\hline \hline Parameter & Target/Comment \\
\hline 1. Endowments & \\
$L_{1400}=147$ & Average firm size of in 1600 of 2.0 (Minns and Wallis, 2012) \\
$\mu=0.925$ & Fraction of non-urban population in 1600 \\
\hline 2. Transport costs & Willan (1976), Masschaele (1993) and Munro (1997) \\
$\tau_{1400}=1.09$ & Drop in average distance between same-size cities (Table 1) \\
$\tau_{1600}=1.07$ & Drop in average distance between same-size cities (Table 1) \\
$\tau_{1800-1850}=1.02$ & \\
\hline 3. Preferences & \\
$\alpha=0.097$ & Urban-rural real wage premium of 33\% between 1400 and 1600 (Clark, 2001) \\
$\beta=0.20$ & Ratio of average city size between 1400 and 1600 (Table 1) \\
\hline $\mathbf{4 . ~ T e c h n o l o g i e s}$ & \\
$\Gamma_{a}=1.0$ & Normalization \\
$\Gamma_{v}=1.0$ & Productivity gains in textile (Randall, 1991) \\
$\gamma=1.5$ & $10 \%$ to 15\% share of time on non-production activities in 1600 \\
$\kappa=0.23$ & $10 \%$ rate of return earned by Bean Ing Mill in 1792-1812 (Hudson, 1986) \\
$\phi=6.250$ &
\end{tabular}

The parameter values are shown in Table 3. As the model structure is not commonly used in the growth literature, we explain in detail how each parameter value was chosen. Starting with

\footnotetext{
${ }^{35}$ Since we assume that the modern technology is always available, the definition of the ARTSE now requires the additional condition that no firm in no industry has an incentive to adopt the modern technology, i.e., $\Pi^{E \prime} \leq 0$.
} 
the parameter values listed under the endowments category, we set the average city size in 1400 so as to generate an average firm size of 2.0 workers in 1600. This firm size is based on work by Minns and Wallis (2012) that documents the average number of apprentices present in the households of masters in several English cities in this period. For example, in Bristol in the seventeenth century the average master employed 1.0 apprentice, whereas in London, this average was larger at 1.6. ${ }^{36}$ The second endowment parameter, $\mu$, requires far less explanation. As it represents the fraction of the population that is unskilled, its value is set to the fraction of the rural population in England in 1600.

Turning to iceberg costs, its values are based on several studies that estimate transport costs in pre-industrial Europe. The average transport cost as a fraction of total costs for the set of goods reported in these studies is $0.1 \%$ per $\mathrm{km}^{37}$ To assign a value for $\tau$, we need to multiply this cost per kilometer by the average distance between cities. In the context of our model, the appropriate distance measure is $S_{3}^{r}$, the average distance for a city to reach the same number of consumers as its own city, reported in Table 1 . As this distance is $93 \mathrm{~km}$ in 1400 , we set $\tau_{1400}=1.09$. The 1600 and 1800-1850 values are then chosen based on the decline in the average distance to same-sized cities. As $S_{3}^{r}$ declined to $70 \mathrm{~km}$ in 1600 and $21 \mathrm{~km}$ between 1800 and 1850 , we set $\tau_{1600}=1.07$ and $\tau_{1800-50}=1.02$.

Moving on to the preference parameters, the assignment of the expenditure share on the industrial goods in the household utility function, $\alpha$, is straightforward: given the fraction of unskilled households, the expenditure share parameter is set so that the wage differential for skilled to unskilled workers in the ARTSE matches the urban-rural wage premium in England between 1400 and 1600 reported by Clark (2001) 38 The assignment of the curvature parameter of the Lancaster compensation function, $\beta$, requires greater explanation as it is one of the parameters specific to our preference structure. To calibrate it, we exploit the fact that the curvature parameter is critical

\footnotetext{
${ }^{36}$ An obvious question is why we did not set the population to the actual 1400 average city size in England. The short answer is that theoretically city size only matters to the extent that it affects firm size, so the relevant target is the firm size. Had we wanted, we could have set $L_{1400}$ to the actual 1400 average city size. Matching firm size would then require adjusting the circumference of the circle. This would not change anything, but it would come at the cost of introducing one more parameter, so we refrain from doing so.

${ }^{37} \mathrm{We}$ base our estimate on information of four different goods: grain, wine, luxury woolens and semi-worsted woolens. Masschaele (1993) finds that transporting grain in 14th century England added around $0.25 \%$ per $\mathrm{km}$ to the price. Based on data from the end of the 16th century, transporting wine from Chester to Smithills increased the price by $0.17 \%$ per $\mathrm{km}$ (Willan, 1976). As for woolen products, Munro (1997) cites different studies. One is based on the writings of a Flemish merchant who exported luxury woolen from Bruges to Barcelona in the late 14th century at a cost of $0.02 \%$ per $\mathrm{km}$. Another study reports a cost of around $0.01 \%$ per $\mathrm{km}$ for semi-worsted woolen products exported from Caen to Florence in the early 14th century. Taking these four numbers, we find an average transport cost of around $0.1 \%$ per $\mathrm{km}$.

${ }^{38}$ Clark (2001) reports wages for urban craftsmen, urban laborers and farm laborers. We estimate the urban wage to be the average of the wages of the urban craftsmen and the urban laborers. We then define the urban-rural wage premium as the ratio of urban to rural wages. We adjust this ratio for the cost of living differences between urban and rural area by using the relative wage of laborers in both places.
} 
for determining the city size threshold at which resistance starts 39 As such, we set $\beta$ so that the GARTSE first exists when the average city size in the model exhibits the same increase as the one experienced by English cities between 1400 and 1600, using the calibrated iceberg costs in those two years.

The last set of parameters are technology related. Because of the Cobb-Douglas nature of preferences between the agricultural good and the industrial goods, any change in relative productivities translates into changes in relative prices, leaving expenditure shares unchanged. From that point of view, the TFP parameters do not affect the market size of the industrial sector. For this reason, the TFP parameters in agriculture, $\Gamma_{a}$, and in industry, $\Gamma_{v}$, are both normalized to one. For the parameter $\gamma$, which governs how much more productive the modern technology is relative to the artisanal technology, we set its value to 1.5, consistent with the reduction in the time input of men making woolen cloth between 1781 and 1796, as summarized by Randall (1991). The fixed operating cost parameter, $\kappa$, is targeted so that skilled workers spend between $10 \%$ and $15 \%$ of their working time on non-production activities in the ARTSE. We are not aware of any historical study documenting the amount of time industrial workers spent in the fifteenth and sixteenth centuries on non-production activities. Absent such evidence, we think that a time allocation between $10 \%$ and $15 \%$ to non-productive activities is reasonable.

This leaves the assignment of the fixed innovation cost parameter, $\phi$. Because the calibration is done so that no firm would introduce the modern technology before 1600, we cannot use observations from this period to tie down its value. What is needed is an observation associated with an actual deviation, where a firm first introduces the modern technology. A good empirical counterpart would be the observed profits or rates of return on a textile mill established in the early phases of the Industrial Revolution. Hudson (1986) provides such an observation. He reports rates of return earned by a number of textile mill owners in the late eighteenth century, with John Gott and his Bean Ing mill being the earliest listed. We take the 1792-1812 reported returns in Table 8 of Hudson (1986) for John Gott's mill, assigning a value for $\phi$ so that the implicit rate of return on fixed cost expenditures in our model, defined as $\Pi^{E \prime} /\left[w_{a}(\phi+\kappa)\right]$, matches this value. This completes the calibration of the model.

\subsection{Evaluating the Theory in the English Historical Mirror}

Having calibrated the model to England between 1400 and 1600, we evaluate its prediction for the date when resistance ends and the modern technology is introduced. Specifically, we set the iceberg cost to its 1800-1850 value, $\tau_{1800-50}=1.02$, and determine the smallest average city size for which the GARTSE ceases to exist. We find that the model predicts that resistance ceases when

\footnotetext{
${ }^{39} \mathrm{~A}$ decrease in the value of $\beta$, i.e., more curvature, makes it harder for an innovating firm to steal away consumers who are closely located to their nearest neighbors on the variety circle. This implies that firms have less of an incentive to introduce the modern technology, thus increasing the threshold at which resistance starts.
} 
the average city is 2.8 times greater than its 1400 size. How does this match up with England's historical record? Going back to Table 1 and assuming a constant exponential growth rate of city size between 1800 and 1850, average city size was 2.8 times greater than its 1400 level in 1822 . Thus, the model predicts that guilds should have stopped blocking labor-saving technology in England in 1822. This is within the main period when guilds ended their resistance to labor-saving technologies.

To provide some additional perspective on the relative importance of the increase in average city size and the increase in inter-city trade for England's industrialization, we perform the following counterfactual experiment: we determine the city size that would have been needed for guilds to form and for resistance to break down if iceberg costs had remained at their 1400 value of 1.09 forever. For this purpose, we renormalize $L_{1400}$ in the model to the actual average English city size in 1400 of 11,200 inhabitants. What the counterfactual reveals is that in the absence of a decline in inter-city distances, guilds would have formed when the city size reached 21,200 and guilds would have disappeared when the city size reached 65,142 . The benchmark predicts that guilds would have started to form when city size reached 19,300 inhabitants and would have ended their resistance when city size reached a population of 31,619. The counterfactual, therefore, suggests that industrialization would have required a city size more than double had inter-city distance remained at its 1400 level. This is a substantial difference, suggesting that the increase in inter-city trade was important for understanding England's early take-off.

\section{Spatial Competition and the Great Divergence}

Having demonstrated that the theory is able to account for the timing of England's take-off, we next explore whether the model offers a plausible explanation for the Great Divergence. We do this in three steps. First, we document the degree of spatial competition in China, showing that it was far less intense compared to England over the relevant time period. Second, we provide a history of the guilds in China, paying particular attention to the period when new labor-saving technology became available. Finally, using data on city sizes and inter-city distances in China, we determine the predictions of our theory for the dates when guilds in China should have started to block labor-saving technology and when they should have disappeared.

\subsection{The Evolution of Spatial Competition in China}

We begin by documenting the important disparity in the degree of spatial competition between China and England. Unlike England, however, there is no readily available panel of city-level population for China for the period under consideration. To construct such a panel, we make use of three different data sources. The first is Yue, Skinner and Henderson (2007), which provides the most detailed historical data on city populations, but only for a single year, 1893. It covers all 2,403 cities that served as administrative capitals of prefectures or counties during the period 
1820-1893. The second data source is Cao (2000), which reports population data for prefectures for 1776, 1820, 1851, 1880 and 1910. The last data source is Maddison (2001) who provides information on urbanization rates in China going back to 1500.

To construct our panel, we begin with the year 1893. The Yue, Skinner and Henderson (2007) data does not report exact city sizes, but rather classifies cities by size bins, with the first bin consisting of cities with less than 500 inhabitants and with the upper limit of each subsequent bin being twice its lower limit, until reaching 512,000. That is, the bins consist of: less than 500; 500 to 1,$000 ; 1,000$ to 2,$000 ; 2,000$ to 4,$000 ; \ldots ; 256,000$ to 512,000 ; and more than 512,000 . Except for the highest bin, we use the mid-value of each bin to define the size of a city's population. For the highest bin, we use city population data from 1900 from Eggimann (1999) ${ }^{40}$ As we did in the English case, we only use the data for cities that had at least 5,000 inhabitants in the year.

For years prior to 1893, we make use of the prefecture-level data collected by Cao (2000) to estimate city size. In particular, we calculate the growth rate of the prefecture populations between consecutive dates given in Cao (2000), and then assume that each of the cities in the Yue, Skinner and Henderson (2007) dataset grow at the same rate as its closest prefecture-level city. With these growth rates and the 1893 city size data, we impute the city population levels in 1776 and 1820. To obtain estimates of city sizes in 1700, we rely on the finding of Maddison (2001) that the urbanization rate in China was stable between 1700 and 1820 . To impute the 1700 city sizes, we therefore assume that cities in China grew at the same rate as the overall population between 1700 and 1820. Of course, these imputations will only yield an approximate picture of the degree of inter-city competition in eighteenth and nineteenth century China. However, as we will later see, our main result will not depend on any imputed numbers. To be precise, our central finding will be the model's prediction that China did not have the conditions to industrialize in 1893, implying that China's industrial revolution did not happen until later in the twentieth century.

\subsubsection{Measures of Spatial Competition}

Before calculating the spatial competition measures developed in Section 2 for China, we present some descriptive statistics that have been used in the literature as proxies for market size in China. These proxies, reported in Table 4, Panels A through C, are total population, urban population and average city size. To facilitate comparisons, we provide the corresponding statistics for England 41 In terms of total population and urban population, China was well ahead of England at any point

\footnotetext{
${ }^{40}$ Note that we cannot use Eggimann (1999) as an alternative source for our overall study of urbanization in China because of the high number of missing data: for 1850 Eggimann (1999) only has data on 62 Chinese cities, and by 1900 that number only increases to 85 .

${ }^{41}$ In order to compare China and England in 1776 and 1820, we have imputed population values for England assuming that city-specific growth rates between two consecutive years in the Bairoch et al. (1988) dataset were constant.
} 
Table 4: Spatial Competition: England and Northwest Europe vs China

\begin{tabular}{|c|c|c|c|c|c|c|c|}
\hline Year & 1600 & 1700 & 1776 & 1800 & 1820 & 1850 & 1893 \\
\hline \multicolumn{8}{|c|}{ A. Total Population (millions) } \\
\hline China & 160 & 138 & & 381 & 412 & 386 & \multirow[b]{2}{*}{24} \\
\hline England & 4 & 5 & & 8 & 10 & 15 & \\
\hline \multicolumn{7}{|c|}{ B. Urban Population (millions) } & \multirow{3}{*}{31.4} \\
\hline China & & 7.8 & 20.0 & & 25.6 & & \\
\hline England & 0.3 & 0.9 & 1.5 & 2.6 & 3.8 & 7.0 & \\
\hline \multicolumn{7}{|c|}{ C. Average City Size (thousands) } & \multirow{3}{*}{31.1} \\
\hline China & & 24.1 & 31.0 & & 33.0 & & \\
\hline England & 19.1 & 25.1 & 30.5 & 21.2 & 30.3 & 50.8 & \\
\hline \multicolumn{7}{|c|}{ D. Population access $\leq 20 \mathrm{~km}\left(S_{1}\right.$, thousands $)$} & \multirow{3}{*}{6.8} \\
\hline China & & 5.2 & 7.0 & & 7.9 & & \\
\hline England & 0.0 & 1.3 & 26.6 & 73.8 & 107.2 & 190.6 & \\
\hline \multicolumn{7}{|c|}{ E. Population access, spatial decay $\delta=1.5\left(S_{2}\right.$, thousands $)$} & \multirow{3}{*}{3.2} \\
\hline China & & 1.2 & 2.4 & & 3.0 & & \\
\hline England & 0.2 & 0.6 & 1.5 & 4.1 & 6.1 & 11.6 & \\
\hline \multicolumn{7}{|c|}{ F. Distance to reach same number of consumers $\left(S_{3}, \mathrm{~km}\right)$} & \multirow{3}{*}{53} \\
\hline China & & 71 & 54 & & 50 & & \\
\hline England & 70 & 44 & 37 & 21 & 21 & 21 & \\
\hline
\end{tabular}

in time over the 1700-1820 period ${ }^{42}$ In contrast, average city size, shown in panel C, was not that much different between China and England.

Comparing these proxies suggests that a theory of the Industrial Revolution based on market size or city size alone is not plausible. Our theory shows why market size or city size per se is not the key factor determining an economy's take-off. What matters, instead, is the degree of spatial competition, which depends on both city size and the amount of trade between cities. If our theory has any hope of explaining the Great Divergence, it must be the case that inter-city competition was more intense in England than in China in the second half of the eighteenth century when labor-saving technologies were widely adopted in England.

This is exactly what the measures of spatial competition for China and England reveal. Panel D reports $S_{1}^{r}$, the population access in a $20 \mathrm{~km}$ radius. This measure of spatial competition shows almost no increase in China between 1700 and 1893. In contrast, in England this measure increased by a factor of 150 between 1700 and 1850. When focusing on 1700-1776, the period leading up to the Industrial Revolution, there was little change in China, whereas spatial competition increased 20-fold in England. Thus, although China was significantly ahead of England by this

\footnotetext{
${ }^{42}$ Rather than comparing China to England, we could focus on Northwest Europe, the broader region to first industrialize, as the relevant counterpart of China. If we take Northwest Europe to be Great Britain, France, Belgium, Netherlands and Germany, the differences become obviously smaller, though China continues to be larger in terms of both its total population and its urban population.
} 
measure in 1700 , this advantage eroded by the middle of the century.

The population access measure that assumes a spatial decay, $S_{2}^{r}$, shows a slightly larger increase in China as well as a slightly lower initial advantage. Again, the increase in England is far larger, so that England surpasses China, albeit only towards the end of the eighteenth century. For the final measure, $S_{3}^{r}$, the average distance for a city to reach a population size equivalent to its own, China displays far less spatial competition starting in 1700 and a far smaller increase in spatial competition between 1700 and 1893. In 1776, on the eve of the Industrial Revolution, the average distance to reach the same number of consumers was about $50 \%$ larger in China than in England. Maybe more tellingly, at the end of the nineteenth century the degree of spatial competition in China had not yet reached the level in England in 1700.

These comparisons suggest that the capacity of the average English city to gain market share at the expense of its close-by neighbors was stronger than that of the average Chinese city for most, if not all, of the period.

\subsection{Guilds in China}

The comparative evolution of spatial competition in China and England is consistent with our theory of the Great Divergence. For our theory to be reasonable, it must also be consistent with the history of organizational and technological change in both countries. We have already documented this for England; the question is whether the same holds for China. More particularly, we are interested in seeing whether the effect of spatial competition on the evolution of technology and organizational forms in China conforms to the predictions of the theory.

The origin of guilds in China dates back to the late-Imperial period. Although China was a single political unit in this period, an individual who traveled to a faraway prefecture or province was at the peril of local officials and strongmen. Accordingly, travelers to a city, most of whom were long-distant merchants, organized themselves according to their place of origin for the purpose of mutual assistance during their stay. Often, but not always, such native-place organizations were called huiguan, hui-kuan or tung-hsiang-hui (meaning "assembly" or "club houses"). Although the names of many of the huiguan referred to a province, membership was usually confined to a smaller area, such as a county, a city, or a few villages.

Although the huiguan catered to the economic interests of their members, they did not monopolize specific sectors. They were thus not a means to protect local professions from outside competition. The situation in the largest city at the time, Beijing, which at some point had over 400 huiguan, is informative (Rozman, 1973). No industry there was controlled by a single huiguan. Instead, in any given industry, many different huiguan, representing different regions in China, had a presence. If anything, the huiguan in this period served to enhance competition by counteracting the monopolistic power of the government-appointed headmen (hangtou or hanglao) who set prices in different crafts and trades. They also increased competition by facilitating long-distance inter- 
regional trade, and in this sense were similar to merchant guilds in Europe 43

As the European merchant guilds, the huiguan declined over time, and were increasingly replaced by European-style occupation-based craft guilds, referred to as gongsuo, literally meaning "public hall" or "meeting place" (Moll-Murata, 2008). It is this type of guilds that will be relevant for our theory. There is no simple way of dividing Chinese guild history into a huiguan and a gongsuo period. Using data from Moll-Murata (2008), Figure 1 shows the relative evolution of huiguan and gongsuo by their founding period 44 As can be seen, the big push towards gongsuo is associated with the second half of the nineteenth century, which coincides with a growing European presence in the region following the Opium Wars and the increasing availability of imported European laborsaving technologies. In terms of our theory, the emergence of craft-based guilds in China should thus be situated in that time period.

Figure 1: Native-place (huiguan) vs Professional (gongsuo) Guilds by Date of Foundation in China

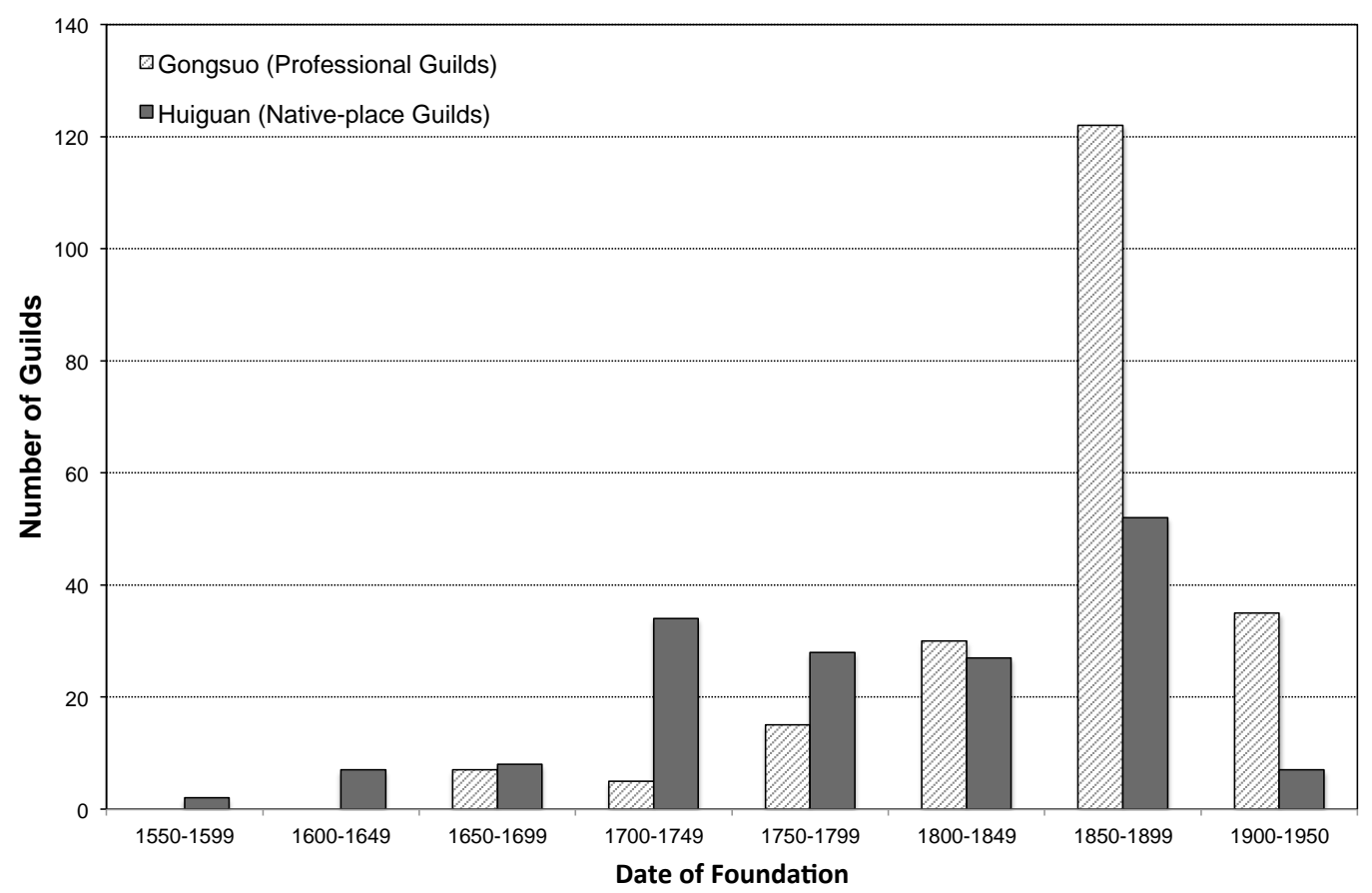

There are a number of other parallels between the gongsuo and the European craft guilds, in addition to both being occupation-based. First, in spite of Chinese cities not being self-governed, the gongsuo were organized at the level of cities (Bradstock, 1983). This implies that for our analysis the city continues to be the relevant unit of analysis, making inter-city competition the appropriate measure of spatial competition. Second, as in Europe, the gongsuo emerged earliest

\footnotetext{
${ }^{43}$ For China see, e.g., Shiue and Keller (2007) and Moll-Murata (2008); for Europe see, e.g., Gelderblom and Grafe (2010).

${ }^{44}$ The database contains 516 named pre-1900 guilds of which 347 can be classified as either huiguan or gongsuo.
} 
in the largest cities. The first gongsuo appeared between 1650 and 1700 in cities such as Beijing, the country's capital, and Suzhou, an important inland port city in Jiangsu province. Third, the Chinese gongsuo pursued policies similar to the European craft guilds prior to the latter's decline. They provided public goods, collected taxes for the authorities, and regulated production, prices and trade.

Although early on the gongsuo did not acquire the same judicial authority over their trades as their European counterparts, they were de facto very effective in monopolizing professions. The evidence reveals that they "establish rules and compel obedience to them; they fix prices and enforce adhesion; they settle or modify trade customs and obtain instant acquiescence; they impose their will on traders in and out of the gilds [sic], and may even, through the measure known as the 'cessation of all business' cause the government to modify or withdraw its orders; and their end, that of having the absolute control of their craft, is obtained by methods of which some are indicated above" (Morse, 1909, p. 31). The gongsuo, thus, obtained "an enormous and almost unrestrained control over their respective trades" (Morse, 1909, p. 21). If anything, at their peak they may have been more powerful than their European counterparts.

The strict control that the gongsuo imposed over their trades greatly hindered innovation, and prevented the introduction of new, labor-saving technologies. For example, as noted in a first-hand account by MacGowan (1886):

Native merchants imported from Birmingham a quantity of thin sheet-brass for manufacturers of brass utensils at Fatshan, throwing out of employment a class of coppersmiths whose business consisted in hammering out the sheets heretofore imported in a thick form; but the trade struck to a man, would have none of the unclean thing, and to prevent a riot among the rowdiest class of the rowdiest city in the empire, the offending metal was returned to Hongkong. Further, a Chinese from America the other day imported thence some powerful sewing machines for sewing the felt soles of Chinese shoes to the uppers, but the native sons of St. Crispin destroyed the machines, preferring to go on as their fathers did, while the enterprising Chinaman returned to Hongkong, a poorer and sadder man. Again, some years ago a progressive Chinaman set up a steam-power cotton mill, only to be made useless by the very simple plan of the growers refusing to send in a pound of cotton. Filatures from France, effecting not only a wonderful saving in time and money but improving the quantity and quality of the output of silk, succeeded at Canton for a while, and were introduced latterly by Chinese capitalists into the silk-rearing districts, only to be destroyed and wrecked by the country-folk" (p. 183).

As MacGowan (1886) suggests, the threat of social disorder was an important factor in preventing labor-saving technology from being introduced. Consider, for example, a report sent from 
China to the Foreign Office in London, concerning the mechanization of cotton cloth production in Shanghai in 1876 :

During the past year [1875-6] an attempt was made to launch a Steam Cotton-Mill Company at this port [Shanghai], for the purpose of manufacturing cotton piece-goods from native-grown cotton ... similar ... to the goods at present made by Chinese ... but with the advantages of English machinery and steam-power, ... When the enterprise came to be generally known to the Chinese newspapers, the attitude of the Cotton Cloth guild became so alarming that the native supporters [of the project] drew back. An idea was unfortunately circulated among the natives, and more particularly amongst the workers of native hand-made cloth, that the trade would be immediately put an end to if such a scheme were put into operation, whereupon the guild passed a resolution to the effect that no clothes made by machinery should be permitted to be purchased... The local officials refused their support or countenance the scheme through fear of causing riots amongst the people..." (Great Britain. Foreign Office. 1875-8. pp. 17-18 in the report for 1877).

The report makes clear that guilds had the power to block new technologies. Attempts to mechanize other industries faced similar barriers. In 1868 for example, Ma (2005) writes that the "fiercest resistance" to mechanizing the silk industry "came from the organized silk handicraft and commercial guilds".

That the fear of riots and social unrest was a stronger factor in inhibiting technological change in China than in England reflects a weaker safety net. There were two main poor relief measures that prevailed under the Qing period: the granary system, run mainly by the state and aimed at alleviating food shortages, and the clan trust, the use of common property by the kin group to assist clan members in need. Both were ill-equipped to handle the challenges of industrialization, as they did little to ameliorate the situation of displaced workers 45 The granary system, already in decline, was not designed to assist the poor, but rather to dampen high grain prices when harvests failed. The clan trust did help the poor, but it was confined to clan members, and hence limited to clans with sufficient resources. The inadequacy of the Chinese poor relief system is an important difference compared to England, in effect giving Chinese workers a greater incentive to organize and block the introduction of labor-saving technology.

Despite this greater incentive to resist and the corresponding threat of social unrest, the status quo became more difficult to maintain. By the late nineteenth century, Chinese industry was increasingly being undermined by the increase in spatial competition and its technological

\footnotetext{
${ }^{45}$ For an in-depth description of these poor relief policies, see Bradstock (1984), Greif, Iyigun and Sasson (2012), Greif and Iyigun (2013) and Will and Wong (1991).
} 
backwardness ${ }^{46}$ As late as 1870, there was no railroad system in China, but by 1913 there were 13,441 kilometers of railroads, greatly facilitating internal trade. By that time China had also become increasingly integrated into the world economy. Whereas at the end of the First Opium War China opened five "treaty ports" to international trade, this number increased to 92 by 1917. The period also witnessed a large inflow of labor-saving technologies from the West, which were superior to their Chinese counterparts: the goods produced with these technologies were either cheaper or better than the Chinese equivalents. As described by a spokesman for the Shanghai builders' guild in the early twentieth century, "our knowledge gradually narrows, our skills deteriorate, and our tools fall out of date. Foreigners then exploit this opportunity to export their goods to our country... The European fad comes sweeping through our country like a flood, and there is no stopping it" (Bradstock, 1984, pp. 228-9).

The increased competition did not only come from abroad, but also from other cities in China. Starting at the end of the nineteenth century, there was an increasing "invasion of one another's preserves" (Bradstock, 1983, p. 151). For example, "the satin guild in Soochow was forced to seek an injunction in 1898 against natives of Nanking who had illicitly begun making certain parts found on looms, a task which had historically been passed down from father to son among a particular subgroup within the guild" (Bradstock, 1984, p. 224).

Just as in England, the rise in conflicts signaled the demise of the Chinese craft guilds. During the late Qing period, in the early-twentieth century, government policy became less favorable towards guild privileges, focusing instead on economic development and growth. During that period the gongsuo began to disband, though the final ones did not disappear until after the victory of the Chinese Communist Party in 1949 (Moll-Murata, 2008). This is consistent with our theory: the decline of the professional guilds in China coincided with the increase in spatial competition, driven by an intensification of foreign competition and a greater integration of China's internal market. It occurred far later in China because the degree of inter-city competition in China lagged that in England by close to two centuries.

\subsection{The Great Divergence}

Having provided a history of Chinese guilds and having shown how their rise and decline relate to the degree of spatial competition, we now explore the implications of our theory for the Great Divergence within our calibrated structure. In particular, we examine whether the greater distance between Chinese cities can explain the delay in China's industrialization.

To determine the city sizes and dates when guilds should have appeared and when they should have started to disappear in China, we need to solve for the model equilibrium using iceberg costs that are relevant for China between 1700 and 1893 . We obtain those by using the same $0.1 \%$

\footnotetext{
${ }^{46}$ For a discussion of other reasons, such as population growth, military defeats and limited taxation capacity, see, for example, Bradstock (1984), Rosenthal and Wong (2011) and Vries (2015).
} 
transport cost per kilometer as in England. As listed in Table 4, Panel F, the distance between same-sized Chinese cities was $71 \mathrm{~km}$ in 1700, $54 \mathrm{~km}$ in 1776 and $53 \mathrm{~km}$ in 1893. This yields an inter-city iceberg cost in China of 1.07 in 1700, 1.05 in 1776 and 1.05 in 1893.

For $\tau=1.05$, the calibrated model implies that guilds should have stopped blocking laborsaving technology in China when average city size reached 38,095. This is more than $20 \%$ above the average city size in 1893 of 31,100. Recall from the historical account of guilds in China that the gongsuo started to disappear in the early twentieth century, with some remaining in existence until the Communist Revolution. This is consistent with our prediction that in 1893 Chinese cities were still about $20 \%$ too small for resistance to break down. We therefore conclude that the theory offers a plausible explanation for China's late development. Since this conclusion only relies on the 1893 data from Yue, Skinner and Henderson (2007), it does not depend on the imputation of city size data in earlier time periods.

Although successful in predicting China's late industrialization, the model is less successful in predicting the date at which technology-blocking guilds formed in China. Using the 1700 iceberg cost for China of 1.07, the model predicts a city size threshold of 19,047 for the appearance of guilds. The average city size in China was already 24,100 in 1700, implying that we should have seen guilds in China by the late seventeenth century. Although a few gongsuo did form in the second half of the seventeenth century, Figure 1 shows that the big shift towards gongsuo happened in the second half of the nineteenth century.

The inability of the model to match the late appearance of technology-blocking guilds in China should not come as a surprise. For resistance to occur, the labor-saving modern technology must first become available. Our reading of the historical evidence strongly suggests that the major labor-saving technologies in China were imported from England, and they did not arrive until after the Treaty of Nanking in 1842, at the end of the First Opium War. In the context of our theory of technology adoption, the question of China's late industrialization is why it failed to materialize once the country got access to modern technologies after its opening up to trade with England. Our theory is able to answer that question: faced in the mid-nineteenth century with new labor-saving technologies coming from overseas, craft guilds emerged to resist industrialization. A separate and equally important issue, not addressed in this paper, is why China did not develop its own labor-saving technologies earlier. In any case, even if they had, our theory predicts that this would not have sped up industrialization. It would simply have prompted the earlier appearance of technology-blocking institutions.

\section{Concluding Remarks}

In this paper we have argued that spatial competition may be a key determinant of long-run development. The novel mechanism we have proposed is based on the interaction between the spatial distribution of cities and the endogenous rise and decline of technology-blocking institutions. 
Because these institutions - which we refer to as guilds - are organized at the level of cities, their monopoly power is limited by the competition from neighboring cities. With strong enough intercity competition, profits from introducing labor-saving technology are sufficient to compensate guild members for the negative effects of innovation, and their resistance breaks down.

We think that this mechanism offers a a plausible explanation for the Industrial Revolution and the Great Divergence. England experienced a large increase in spatial competition in the seventeenth and eighteenth centuries. In a calibrated version of our model, this increase in inter-city competition is able to predict the timing of England's take-off. Historical and empirical evidence further supports the hypothesis that spatial competition critically affected the incentives of firms to adopt new technologies and the incentives of skilled workers to block those innovations. When comparing China to England, our model correctly predicts the later development of China. Although China's cities were similar in size to England's, they were geographically much farther apart. The lower intensity of spatial competition in China meant that industries in a particular city could not easily capture customers of those same industries in neighboring cities, making it less likely for guilds to give up resistance.

The mechanism described in this paper can be used to gain insight into a number of other issues. One such area relates to the argument that political fragmentation contributed to Europe's earlier take-off. One interpretation, favored by Jones (1981) and Lagerlöf (2014), is that inter-state competition for resources spurred military innovation that spilled over into civil society. Extending our model to the national level would provide an alternative interpretation based on the relation between inter-state competition and innovation. This would be consistent with Mokyr (2007) who describes how political fragmentation led to a competitive market for talent in Europe. Another area that deserves further attention relates to the geographic span of technology-blocking institutions. Whereas craft guilds were typically organized at the level of industries and cities, in a world with greater inter-city competition we would expect guilds to endogenously expand their reach to control multiple cities. In fact, as the Industrial Revolution unfolded, we saw the emergence of social movements, such as trade unions, organized at the national, and sometimes even at the international, level.

\section{References}

[1] Aghion, P., Bloom, N., Blundell, R., Griffith, R. and Howitt, P., 2005. "Competition and Innovation: an Inverted-U Relationship," Quarterly Journal of Economics, 120, 701-728.

[2] Allen, R. C., Bassino, J.-P., Ma, D., Moll-Murata, C., and van Zanden, J. L., 2011. "Wages, Prices, and Living Standards in China, 1738-1925: In Comparison with Europe, Japan, and India," Economic History Review, 64, S1, 8-38. 
[3] Bairoch, P., Batou, J., and Chèvre, P., 1988. La population des villes européennes de 800 à 1850. Centre d'Histoire Economique Internationale de l'Université de Genève, Librairie Droz.

[4] Barro., R. J. 1991. "Economic Growth in a Cross Section of Countries," Quarterly Journal of Economics, 106, 407-443.

[5] Binfield, K., 2004. Writings of the Luddites. Baltimore: Johns Hopkins University Press.

[6] Bogart, D. 2005. "Turnpike Trusts, Infrastructure Investment, and the Road Transportation Revolution in Eighteenth-Century England," Journal of Economic History, 65, 540-543.

[7] Bradstock, T. R., 1983. "Ch'ing Dynasty Craft Guilds and Their Monopolies," Tsing Hua Journal of Chinese Studies, NS 15, 1430-53.

[8] Bradstock, T. R., 1984. Craft Guilds in Ch'ing Dynasty China. Unpublished PhD Dissertation, Harvard University.

[9] Britnell, R. 2008 [2000]. "The Economy of British Towns 1300-1540," in: Palliser, D.M. (ed.), The Cambridge Urban History of Britain, Vol. 1, Chapter 14. Cambridge: Cambridge University Press.

[10] Broadberry, S., and Gupta, B., 2006. "The Early Modern Great Divergence: Wages, Prices and Economic Development in Europe and Asia, 1500-1800," Economic History Review, LIX, $2-31$.

[11] Cao, S., 2000. Zhongguo renkoushi: Qing shiqi (Population history of China: Qing period). Shanghai: Fudan University Press.

[12] Clark, G., 2001. "The Secret History of the Industrial Revolution," UC Davis, unpublished working paper.

[13] Clark, G. 2007. A Farewell to Alms: A Brief Economic History of the World. Princeton: Princeton University Press.

[14] Daudin, G. 2010. Domestic Trade and Market Size in Late $18^{\text {th }}$ Century France. Journal of Economic History, 70, 716-743.

[15] Daumal, M. and Zignago, S., 2010. "Measure and Determinants of Border Effects of Brazilian States," Papers in Regional Science, 89, 735-758.

[16] De la Croix, D., Doepke, M. and Mokyr, J., 2018. "Clans, Guilds and Markets: Apprenticeship Institutions and Growth in the pre-Industrial Economy," Quarterly Journal of Economics, 133, $1-70$. 
[17] Dent, C., 2007. "Patent Policy in Early Modern England: Jobs, Trade, and Regulation," Legal Studies Research Paper no. 237, Melbourne Law School.

[18] Desmet, K. and Parente, S. L., 2010. "Bigger is Better: Market Size, Demand Elasticity and Innovation," International Economic Review, 2010, 51, 319-333.

[19] Desmet, K. and Parente, S. L., 2012. "The Evolution of Markets and the Revolution of Industry: A Unified Theory of Growth," Journal of Economic Growth, 17, 205-234.

[20] Desmet, K. and Parente, S. L., 2014. "Resistance to Technology Adoption: The Rise and Decline of Guilds," Review of Economic Dynamics, 17, 437-458.

[21] Dinopoulos, E. and Syropoulos, C., 2007. "Rent Protection as a Barrier to Innovation and Growth," Economic Theory 32, 309-332.

[22] Eden, F. M., Sir, 1797. The State of The Poor; Or, An History of The Labouring Classes In England, From The Conquest To The Present Period, Vols. i-iii. London: J. Davis.

[23] Eggimann, G., 1999. La population des villes du tiers monde, 1500-1950. Centre d'Histoire Economique Internationale de l'Université de Genève, Librairie Droz.

[24] Epstein, S. R., 1998. "Craft Guilds, Apprenticeship and Technological Change in Preindustrial Europe," Journal of Economic History, 53, 684713.

[25] Epstein, S. R., 2008. "Craft Guilds in the Pre-Modern Economy: A Discussion," Economic History Review, 61, 155-74.

[26] Foreign Office (Great Britain), 1875-8. Commercial Reports from Her Majesty's Consuls in China. London: Harrison \& Sons.

[27] Gadd, I. A. and Wallis, P., 2002. Guilds, Society 8 Economy in London 1450-1800, London: Centre for Metropolitan History.

[28] Galdón-Sánchez, J. E. and Schmitz, J. A., Jr. 2002. "Competitive Pressure and Labor Productivity: World Iron-Ore Markets in the 1980s," American Economic Review, 92, 1222-35.

[29] Galor, O. and Moav, O., 2002. "Natural Selection and the Origin of Economic Growth," Quarterly Journal of Economics, 117, 1133-1192

[30] Gelderblom, O. and Grafe, R., 2010. "The Rise and Fall of the Merchant Guilds: Re-thinking the Comparative Study of Commercial Institutions in Premodern Europe," Journal of Interdisciplinary History, 40, 477-511.

[31] Greif, A., 2006. "Family Structure and European Institutional Exceptionalism: the Origin of Corporations," American Economic Review Papers 83 Proceedings, 96, 308-312. 
[32] Greif, A. and Iyigun, M., 2013. "Social Organizations, Violence, and Modern Growth," American Economic Review Papers \& Proceedings, 103, 53438.

[33] Greif, A., Iyigun, M. and Sasson, D., 2012. "Social Organizations, Risk Sharing Institutions and Economic Development," in: Aoki, M. (ed.), Proceedings of the 16th World Congress of the International Economic Association.

[34] Gross, C., 1890. The Gild Merchant. Oxford: Clarendon Press.

[35] Harris, C.D. 1954. "The Market as a Factor in the Localization of Industry in the United States," Annals of the Association of American Geographers, 44, 315-348.

[36] 't Hart, M. C., 1993. "Freedom and Restrictions: State and Economy in the Dutch Republic, 1570-1670," in: Davids, K. and Noordegraaf, L. (eds.), The Dutch Economy in the Golden Age. Amsterdam: Nederlands Economisch-Historisch Archief.

[37] Helpman, E. and Krugman, P. R., 1985. Market Structure and Foreign Trade. Cambridge: MIT Press.

[38] Hibbert, F. A., 1891. The Influence and Development of English Gilds. New York: Sentry Press.

[39] Hickson, C. R. and Thompson, E. A., 1991. "A New Theory of Guilds and European Economic Development," Explorations in Economic History, 28, 127-68.

[40] Holmes, T. J., and Schmitz, J. A., 1995. "Resistance to Technology and Trade between Areas," Federal Reserve Bank of Minneapolis Quarterly Review, 19, 2-17

[41] Hotelling, H. 1929. Stability in Competition. Economic Journal, 39, 41-57.

[42] Hudson, P., 1986. The Genesis of Industrial Capital. Cambridge, New York City and Melbourne: Cambridge University Press.

[43] Hummels, D. and Lugovskyy, V., 2009. "International Pricing in a Generalized Model of Ideal Variety," Journal of Money, Credit and Banking, 41, 3-33.

[44] Jacks, D. S., Meissner, C. M., and Novy, D., 2011. "Trade Booms, Trade Busts, and Trade Costs," Journal of International Economics, 83, 185-201.

[45] Jones, E. L., 1981. The European Miracle. Cambridge: Cambridge University Press.

[46] Kelly, M. 1997. "The Dynamics of Smithian Growth," Quarterly Journal of Economics, 112, 939-64.

[47] King, S., 2000. Poverty and Welfare in England 1700-1850. Manchester University Press. 
[48] Kleineke, H., 2006. Borough Market Privileges the Hinterland of Medieval London, C.1400, London: British History Online http://www.british-history.ac.uk/no-series/borough-marketprivileges/1400 [accessed 8 July 2016].

[49] Kremer, M., 1993. "Population Growth and Technological Change: One Million B.C. to 1990," Quarterly Journal of Economics, 108, 681-716.

[50] Krusell, P. and Rios-Rull, J.V., 1996. "Vested Interests in a Positive Theory of Stagnation and Growth," Review of Economic Studies, 63, 301-329.

[51] Lagerlöf, N.-P., 2014. "Population, Technology and Fragmentation: the European Miracle Revisited," Journal of Development Economics 108, 87-105.

[52] Lancaster, K., 1979. Variety, Equity and Efficiency. New York: Columbia University Press.

[53] Letwin, W., 1954. "The English Common Law Concerning Monopolies," University of Chicago Law , 21, 355-385.

[54] Ma, D., 2005. "Between Cottage and Factory: the Evolution of Chinese and Japanese SilkReeling Industries in the Latter Half of 19th Century," Asia Pacific Economy, 10, 195-213.

[55] MacGowan, J., 1886. "Chinese Guilds or Chambers of Commerce and Trade Unions," Journal of the China Branch of the Royal Asiatic Society for the Year 1886, XXI, new series, no. 1, 2, Article VIII, 133-92.

[56] MacLeod, C., 1998. Inventing the Industrial Revolution: The English Patent System, 16601800. Cambridge: Cambridge University Press.

[57] Maddison, A., 2001. The World Economy: A Millennium Perspective. Paris: Development Centre of the OECD.

[58] Masschaele, J., 1993. "Transport Costs in Medieval England," Economic History Review, 46, 266-279.

[59] McCloskey, D. 2010. Bourgeois Dignity: Why Economics Can't Explain the Modern World. Chicago and London: The University of Chicago Press.

[60] Minns, C. and Wallis, P., 2012. "Rules and Reality: Quantifying the Practice of Apprenticeship in Early Modern England," Economic History Review, 65, 556-579.

[61] Mokyr, J., 1990. The Lever of Riches. Technological Creativity and Economic Progress. New York: Oxford University Press.

[62] Mokyr, J., 1997. "The Political Economy of Technological Change: Resistance and Innovation in Economic History," Northwestern University. 
[63] Mokyr, J., 1998. "Invention and Rebellion: Why Do Innovations Occur At All? An Evolutionary Approach," Northwestern University.

[64] Mokyr, J., 2007. "The Market for Ideas and the Origins of Economic Growth in Eighteenth Century Europe," Tijdschrift voor Sociale en Economische Geschiedenis, 4, 3-38.

[65] Moll-Murata, C., 2008. "Chinese Guilds from the Seventeenth to the Twentieth Centuries: An Overview," International Review of Social History, Supplement, 213-247.

[66] Morison, E. E. 1966. Men, Machines, Modern Times. Cambridge, Mass.: Cambridge University Press.

[67] Morse, H. B., 1909. The Gilds of China. London: Longmans, Green and Co.

[68] Munro, J. H., 1997. "The Origin of the English 'New Draperies': The Resurrection of an Old Flemish Industry, 1270-1570," in: Harte, N.B. (ed.), The New Draperies in the Low Countries and England, 1300-1800. Oxford: Oxford University Press.

[69] Nickell, S. J., 1996. "Competition and Corporate Performance," Journal of Political Economy, 104, 724-46.

[70] North, D. C., 1981. Structure and Change in Economic History. New York: Norton.

[71] Ogilvie, S., 2004. "Guilds, Efficiency, and Social Capital: Evidence from German ProtoIndustry," Economic History Review, 57, 286-333.

[72] Ogilvie, S., 2008. "Rehabilitating the Guilds: A Reply," Economic History Review, 61, 175182.

[73] Parente, S. L. and Prescott, E. C., 1999. "Monopoly Rights: A Barrier to Riches," American Economic Review, 89, 1216-1233.

[74] Peretto, P. F., 1998. "Technological Change, Market Rivalry, and the Evolution of the Capitalist Engine of Growth," Journal of Economic Growth, 3, 53-80.

[75] Pirenne, H., 1936. Economic and Social History of Medieval Europe. New York: Harcourt Brace \& World.

[76] Pomeranz, K., 2000. The Great Divergence: China, Europe, and the Making of the Modern World Economy. Princeton, NJ: Princeton University Press.

[77] Randall, A., 1991. Before the Luddites: Custom, Community, and Machinery in the English Woolen Industry, 1776-1809. Cambridge University Press, Cambridge. 
[78] Richardson, G., 2004. "Guilds, Laws, and Markets for Manufactured Merchandise in Latemedieval England," Explorations in Economic History, 41, 1-25.

[79] Rosenthal, J.-L. and Wong, B. R., 2011. Before and Beyond Divergence. Cambridge, Mass.: Harvard University Press.

[80] Rozman, G., 1973. Urban Networks in Ch'ing China and Tokugawa Japan. Princeton, NJ: Princeton University Press.

[81] Schmitz, J. A., 2005. "What Determines Productivity? Lessons from the Dramatic Recovery of the US and Canadian Iron Ore Industries Following their Early 1980s Crisis," Journal of Political Economy, 115, 582-625.

[82] Seligman, E. R. A., 1887. "Two Chapters on the Mediaeval Guilds of England," Publications of the American Economic Association, 2, 9-113.

[83] Shiue, C. H. and Keller, W., 2007. "Markets in China and Europe on the Eve of the Industrial Revolution," American Economic Review, 97, 1189-1216.

[84] Slack, P., 1999. From Reformation To Improvement: Public Welfare in Early Modern England. Oxford: Oxford University Press.

[85] Smith, A., 1776. An Inquiry into the Nature and Causes of the Wealth of Nations [17r6], edited by E. Cannan. Chicago: Chicago University Press.

[86] Solar, P. M., 1995. "Poor Relief and English Economic Development Before the Industrial Revolution," Economic History Review, New Series, 48, 1-22.

[87] Szostak, R., 1991. The Role of Transportation in the Industrial Revolution. Buffalo, NY: McGill-Queens University Press.

[88] Voigtländer, N. and Voth, H.-J., 2006. "Why England? Demographic Factors, Structural Change and Physical Capital Accumulation during the Industrial Revolution," Journal of Economic Growth, 11, 319-61.

[89] Vries, P., 2015. State, Economy and the Great Divergence: Great Britain and China, 1680s1850s. Bloomsbury Academic.

[90] Will, P.-É. and Wong, B. R., 1991. Nourish the People. The State Civilian Granary System in China, with Lee, J., Center of Chines Studies: University of Michigan.

[91] Willan, T. S., 1976. The Inland Trade: Studies in English Internal Trade in the Sixteenth and Seventeenth Centuries. Manchester: Manchester University Press. 
[92] Woodcroft, B., 1854. Chronological Index of Patentees and Applicants for Patents of Invention from March 2, 1614 (14 James I) to October 1, 1852 (16 Victoria). London, Patent Office.

[93] Yue, Z., Skinner, G. W., and Henderson, M., 2007. ChinaW Dataset. Davis: University of California, Regional Systems Analysis Project. 